\title{
Species of the sponge genus Chondrilla (Demospongiae: Chondrosida: Chondrillidae) in Australia
}

\author{
J. fromont ${ }^{1}$, K.L. Usher ${ }^{2}$, D.C. Sutton ${ }^{3}$, S. Toze ${ }^{4}$ and J. Kuo ${ }^{5}$ \\ 'Western Australian Museum, Locked Bag 49, Welshpool DC, Western Australia 6986, Australia \\ 2CSIRO Land and Water, Private Bag no.5, Wembley, Western Australia 6913, Australia \\ SSchool of Biomedical, Biomolecular and Chemical Sciences, University of Western Australia, \\ Crawley, Western Australia 6009 , Australia \\ ${ }^{*}$ CSIRO Water for a Healthy Country, Queensland Biosciences Precinct, \\ St Lucia, Queensland 4067, Australia \\ Centre for Microscopy, Characterisation and Analysis, University of Western Australia, \\ Crawley, Western Australia 6009. Australia
}

\begin{abstract}
A new sponge species, Chondrilla linnael, from Australia is described. Chondrilla australiensis Carter 1873 and C. secunda Lendenfeld 1885 are redescribed with reference to type and new material. The synonymy of C. corticata and $C$. papillata with $\dot{C}$. australiensis is confirmed. Two species previously described from Australia, $C$. mixta and $C$. mucula are discussed, with the conclusion that $C$.mocula is unlikely to occur in Australia. The descriptions of the species incorporate previous molecular results. Information about symbiont relationships and the biogeographical distribution of the species is discussed.
\end{abstract}

Keywords: taxonomy, systematics, sponges, Porifera, Chondrilla

\section{INTRODUCTION}

Approximately twenty species of Chondrilla Schmidt 1862 appear to be valid worldwide (Boury-Esnault 2002). However, the morphology and skeletal structures of this genus and its sister genus (Chondrosia) are remarkably uniform, with few characters useful for differentiation at the species level. Consequently at least two species of Chondrilla have been considered to be globally widespread. The type species, C. mucula Schmidt 1862 was thought to have a cosmopolitan distribution, and C. australiensis Carter 1873 was reported with a widespread Indo-Pacific distribution (Hooper and Wiedenmayer 1994). Recent genetic studies have reduced the known distribution of C. mucula to the Mediterranean Sea (Klautau ef al. 1999).

Six species of the genus Chondrilla have been reported from Australian waters. These include C. australiensis, C. secunda Lendenfeld 1885 and $C$. nucula from mainland Australia, and $C$. mixta Schulze 1877 from Christmas Island, an Australian Territory in the Indian Ocean. Two others, C. papillata Lendenfeld 1885 and C. corticata Lendenfeld 1885 , are regarded as synonyms of $C$. australiensis (Burton 1924). On the basis of DNA sequence analyses of Chondrilla specimens from Australian waters, Usher et al. (2004a) suggested the presence of three species: C. australiensis and two unidentified species described here. A specimen collected from Australia and previously identified as C. nucula was examined and found to be the new species described in this paper. Although fieldwork was undertaken at Christmas Island C. mixta was not found. This study reports three valid species of Chondrilla from mainland Australia: C. australiensis, C. secunda and C. limaei. The occurrence of C. mixta in Australian waters was not resolved.

Species of Chondrilla have been reported from shallow waters ( $<50 \mathrm{~m}$ depth) in tropical, subtropical and temperate zones, but rarely in deeper waters (Boury-Esnault 2002). Many species are considered to be cryptic, occurring on vertical walls, at cave entrances, and under rocks (BouryEsnault 2002). In south Western Australia C. australiensis is a major space occupant of many temperate limestone reef habitats, and forms large encrustations in shallow depths $(1-20 \mathrm{~m})$ in full light and shaded environments (Usher et al. 2001). Individuals of this species have been reported to provide refuge for a wide range of invertebrates including brittle stars, molluscs and shrimp (Edgar 1997), and to be a food item for species of the cowrie genus Zoila (Wilson and Clarkson 2004). Chondrilla aff. mucula from Caribbean coral reefs have been found to be a preferred food of 
the Hawksbill turtle (Meylan 1988) and some fishes (Randall and Hartman 1968).

Species of Chondrilla have been reported to have abundant populations of symbiotic bacteria in their mesohyl (Boury-Esnault 2002), and C. australiensis has been found to have both bacteria (Dey et al. 2004) and symbiotic cyanobacteria (Usher et al. 2001, 2004c). Cyanobacterial symbionts are thought to aid in the rapid growth of larvae at settlement (Wilkinson 1992), and to provide an advantage to adult sponges in competition with algae and other photosynthetic organisms for substrate in high light areas (Wilkinson 1983). In February 1998 a bleaching event was reported for a population of C. australiensis at Fremantle (south Western Australia), which coincided with a global hard and soft coral bleaching event (Fromont and Garson 1999).

Recently, Chondrilla, Chondrosia and two other genera were united in a monophyletic order, Chondrosida, based on molecular data (BouryEsnault and Lopès 1985), and containing a single valid family, Chondrillidae Gray 1872. Prior to 1985 the family was located in the order Hadromerida but its affinities to this order were not clear.

This study documents species of Chondrilla recently collected from Australian waters. Type material of species reported from Australia has been examined and reallocated where necessary. Species currently known to occur in Australia are described and a preliminary assessment of the biogeography of each species is provided. The study also draws on previously published molecular data sets (Usher et al. 2004a) and various biological characters such as symbiont relationships, reproductive biology and ecological distributions.

\section{MATERIALS AND METHODS}

Preserved material from various museums (listed at the end of this section) was examined during the course of this study. Collected specimens were preserved in $70 \%$ ethanol. Skeletal structure and spicule morphology were examined using light microscopy and scanning electron microscopy (SEM). Spicules were prepared by boiling small pieces of sponge (including the ectosome and choanosome) in concentrated nitric acid, followed by two consecutive washes with both distilled water and absolute alcohol. The resulting spicule extracts were dried on a glass slide and mounted in Shandon EZ-Mount (Thermo Electron Corporation). Spicule dimensions were determined by measurement of 20 randomly selected spicules per specimen using an eyepiece graticule with an Olympus BX50 microscope. Clean spicules were spread on coverslips or double-sided carbon tape attached to SEM stubs, dried at $70^{\circ} \mathrm{C}$ and sputter coated with gold prior to examination with a Philips SEM 505 or a Zeiss 1555 SUPRA Variable Pressure SEM operating at $15 \mathrm{kV}$. Images were recorded electronically.

The skeleton was prepared for examination by cutting a representative section at right angles to the surface of the sponge. The section was dehydrated through an ascending ethanol series, cleared in xylene and infiltrated in paraffin wax (Shandon Histoplast) using an automatic tissue processor on a nine hour cycle. The sponge tissue was further infiltrated with paraffin under a vacuum of $635 \mathrm{~mm} \mathrm{Hg}$ for $30 \mathrm{~min}$ prior to embedding. Blocks were sectioned at $90 \mu \mathrm{m}$ thickness with a Leitz slide microtome, and section rolling was eliminated by placing filter paper, moistened with distilled water, on top of the paraffin block. Sections were placed on a glass slide smeared with egg albumin for adhesion, dried overnight at $60^{\circ} \mathrm{C}$, and dehydrated in two changes of xylene. Sections were mounted in Shandon EZ-Mount and examined using light microscopy. Images were recorded with a Leica DFC420 camera on a Leica DME microscope and saved electronically.

All sequences are available on GenBank (accession numbers, D2 region: AY190190AY190224, ITS region: AY190225-AY190239). Methods to determine sequence comparisons and phylogenetic trees are detailed in Usher et al. (2004a).

Abbreviations used in the text: AM, Australian Museum, Sydney, Australia; BMNH, Natural History Museum, London, United Kingdom; LMJG, Landesmuseum Joanneum, Graz, Austria; NMV, National Museum of Victoria, Melbourne, Australia; NTM, Northern Territory Museum of Arts and Sciences, Darwin, Australia; SAM, South Australian Museum, Adelaide, Australia; WAM, Western Australian Museum, Perth, Australia; ZMB, Museum fuer Naturkunde, Berlin, Germany.

\section{SYSTEMATICS}

\section{Order Chondrosida Boury-Esnault and Lopès 1985}

\section{Family Chondrillidae Schmidt 1862}

\section{Chondrilla Schmidt 1862}

\section{Type species}

Chondrilla nucula Schmidt, 1862 (subsequent designation by de Laubenfels, 1936).

Chondrilla linnaei sp. nov. Figures 1a, 1b, 2-4 

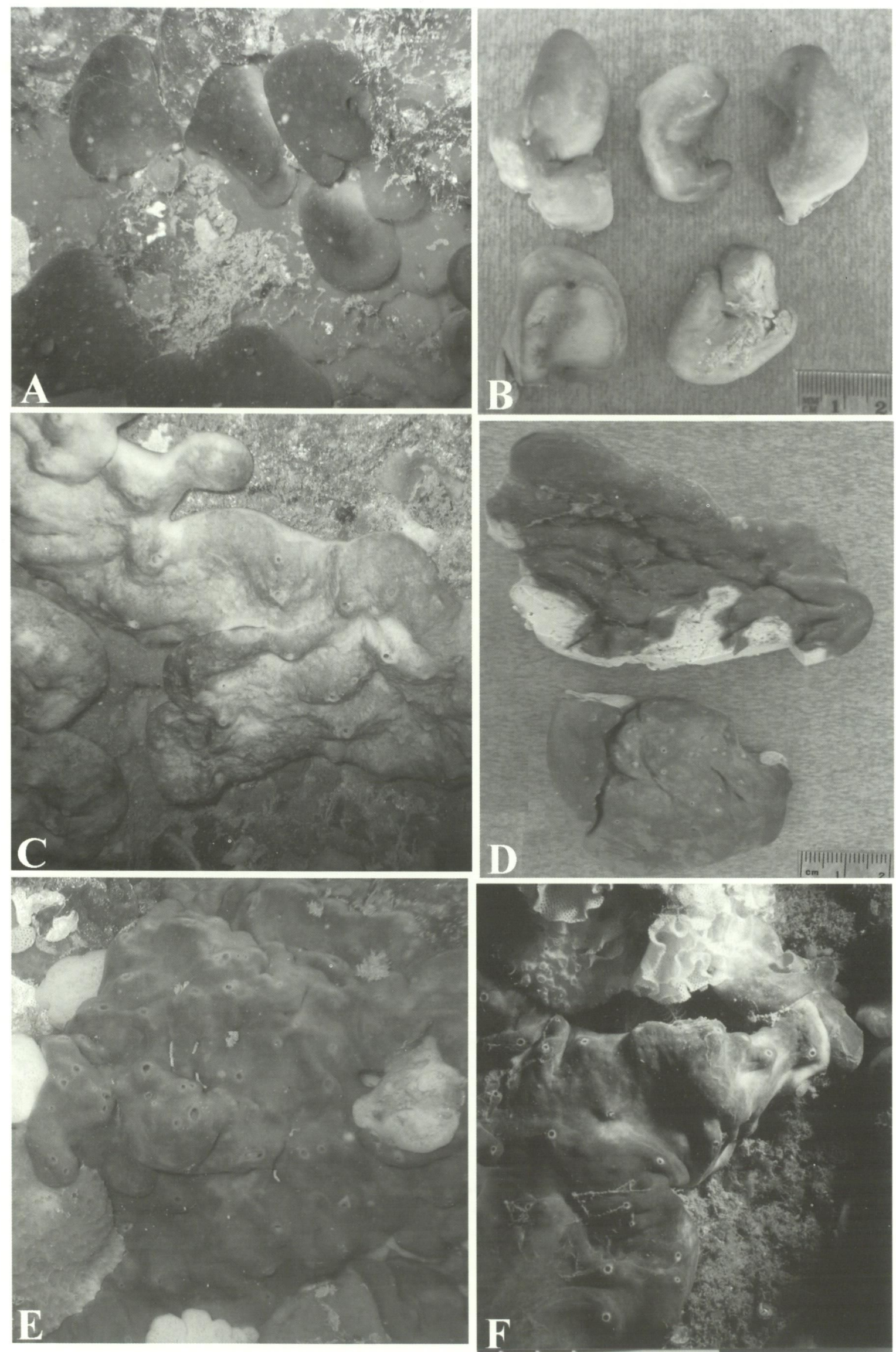

Figure 1 Whole specimen images of Australian Chondrilla. A. C. linnaei in situ. B. Holotype (WAM Z13267) of C. linnaei after preservation in ethanol. C. C. secunda in situ. D. C. secunda after preservation in ethanol (WAM Z13262). E. C. australiensis in situ. F. C. australiensis in situ, maroon form. 


\section{Material examined}

Holotype

Australia: Western Australia: 5 pieces, in cave, Twilight Cove, Esperance, 33⒌'S, $121^{\circ} 55^{\prime} \mathrm{E}, 9.2$ $\mathrm{m}$ depth, K. Usher, SCUBA, 3 May 2001 (WAM Z13267).

\section{Paratypes}

Australia: South Australia: 1 specimen, Western River Cove, Kangaroo Island, $35^{\circ} 40^{\prime} \mathrm{S}$, 136 $57^{\prime} \mathrm{E}, 3-11 \mathrm{~m}$ depth, K. Usher, SCUBA, 8 November 2001 (SAM S1106, ex WAM Z13276). Western Australia: 3 pieces, Mistaken Island, Albany, $35^{\circ} 03^{\prime} \mathrm{S}, 117^{\circ} 58^{\prime} \mathrm{E}, 8.0 \mathrm{~m}$ depth, K. Usher, SCUBA, 6 May 2001 (WAM Z13256); 1 specimen,

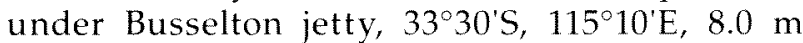
depth, K. Usher, SCUBA, 21 February 2001 (WAM Z13259); 2 pieces, station JWAM08 transect 1, Essex Rocks Jurien, 30²1.15'S, $114^{\circ} 59.30^{\prime} \mathrm{E}, 7-11 \mathrm{~m}$, J. Fromont, SCUBA, 1 May 2005 (WAM Z31397).

\section{Other material examined}

Australia: Tasmania: 1 specimen, Maria Island, ca. $42^{\circ} 38^{\prime}$ S, $148^{\circ} 05^{\prime} \mathrm{E}$ (BMNH 1925.11.1.1331); South Australia: 1 specimen, Western River Cove, Kangaroo Island, 35 40'S, $136^{\circ} 57^{\prime} \mathrm{E}, 9.0 \mathrm{~m}$ depth, $\mathrm{K}$. Usher, SCUBA, 8 May 2001 (WAM Z13275).

\section{Diagnosis}

Chondrilla linnaei is characterised by always forming small, discrete encrusting mounds or lobes, a finely speckled surface in darker shades of brown with a lighter interior, and small oxysphaerasters as the only spicule type. Diameter from ray tip to opposing ray tip varies among specimens (range 15.7-18.4 $\mu \mathrm{m}$, mean 17.6 $\mu \mathrm{m}, \mathrm{n}=140$ ).

\section{Description}

Habitus as in Figure 1a, b. Thickly encrusting with a smooth, shiny surface. Individuals tend to form small thick discrete encrustations or low lobes up to $30 \mathrm{~mm}$ high with apical oscules approximately $3 \mathrm{~mm}$ wide in preserved sponges. Oscules may have slightly raised rims up to $1 \mathrm{~mm}$ in height. Dimensions: The holotype consists of five discrete lobes, the largest of which is $45 \times 20 \times 18$ $\mathrm{mm}$ high. Texture: soft alive, but firm, compressible and springy after preservation. Sponges have a dense compact interior with fine internal canals. Colour: finely speckled shades of brown to dark brown with a cream, fawn or brown interior. WAM Z13256 has an orange tinge. Some specimens are pigmented throughout the choanosome, with more dense pigmentation towards the surface and around internal canals, although degree of pigmentation varies among specimens.
General organisation: (Figure 2a, b). Ectosome: oxysphaerasters form a single layer at the surface or are sparsely distributed throughout this layer. This region is $320-1000 \mu \mathrm{m}$ thick and is usually apparent macroscopically. Choanosome: oxysphaerasters are distributed throughout the choanosome, but tend to be more numerous around internal canals, where they may form a single boundary layer. The mesohyl of the choanosome is clearly differentiated from the ectosome.

Spicules: (Figure 2c-e). Oxysphaerasters usually with fine sharply pointed spines, occasionally with blunt spines and a more ball-like shape. Diameter from ray tip to opposing ray tip varies among specimens (range 15.7-18.4 $\mu \mathrm{m}$, mean 17.6 $\mu \mathrm{m}, \mathrm{n}=140$ ) (Table 1).

Cyanobacteria: sponges were found to contain cyanobacteria in low concentrations with $99.7 \%$ partial sequence similarity to Synechococcus WH 8103 (Genbank), a species which occurs in the water column (Usher et al. 2004c).

\section{Remarks}

This species is comparable in spicule type to Chondrilla nucula Schmidt 1862 having a single size category of oxysphaeraster. The specimen from Tasmania examined in this study (BMNH 1925.11.1.1331) was previously identified as $C$. nucula by Shaw. We examined that specimen and have assigned it to the new species $C$. linnaei. Chondrilla nucula has also been reported from the Great Barrier Reef (Burton 1934). This material requires checking but it is unlikely that $C$. nucula is present in Australia, and more likely that early records are of a different species, possibly the new species described here.

We compared our specimens of Chondrilla linnaei to the type material of C. nucula, type locality Adriatic Sea (holotype LMJG 15108/0 and paratypes LMJG 15687/0 and BMNH 1867.7.26.1). The average size of the oxysphaerasters of these specimens was 27,26 and $31 \mu \mathrm{m}$, respectively ( $\mathrm{n}=20$ ) (Table 1, Figure 2f). We also obtained recently collected fresh material of $C$. nucula from Marseille and Portofino in the Mediterranean (WAM Z13268 and Z13261, respectively) and found similar average spicule sizes (26 and 25 $\mu \mathrm{m}$, respectively; $\mathrm{n}=20$ ) to the type material. Sequences of these $C$. nucula specimens showed $100 \%$ similarity to each other and $89.1 \%$ similarity to the C. linnaei holotype Z13267 (Figure 3). The two species are clearly differentiated by spicule morphology and size, molecular dissimilarity, and geographic locality.

We also examined a specimen of Chondrilla from Bermuda (BMNH 1948.8.6.55) and found oxysphaerasters with an average size of $23 \mu \mathrm{m}$ 

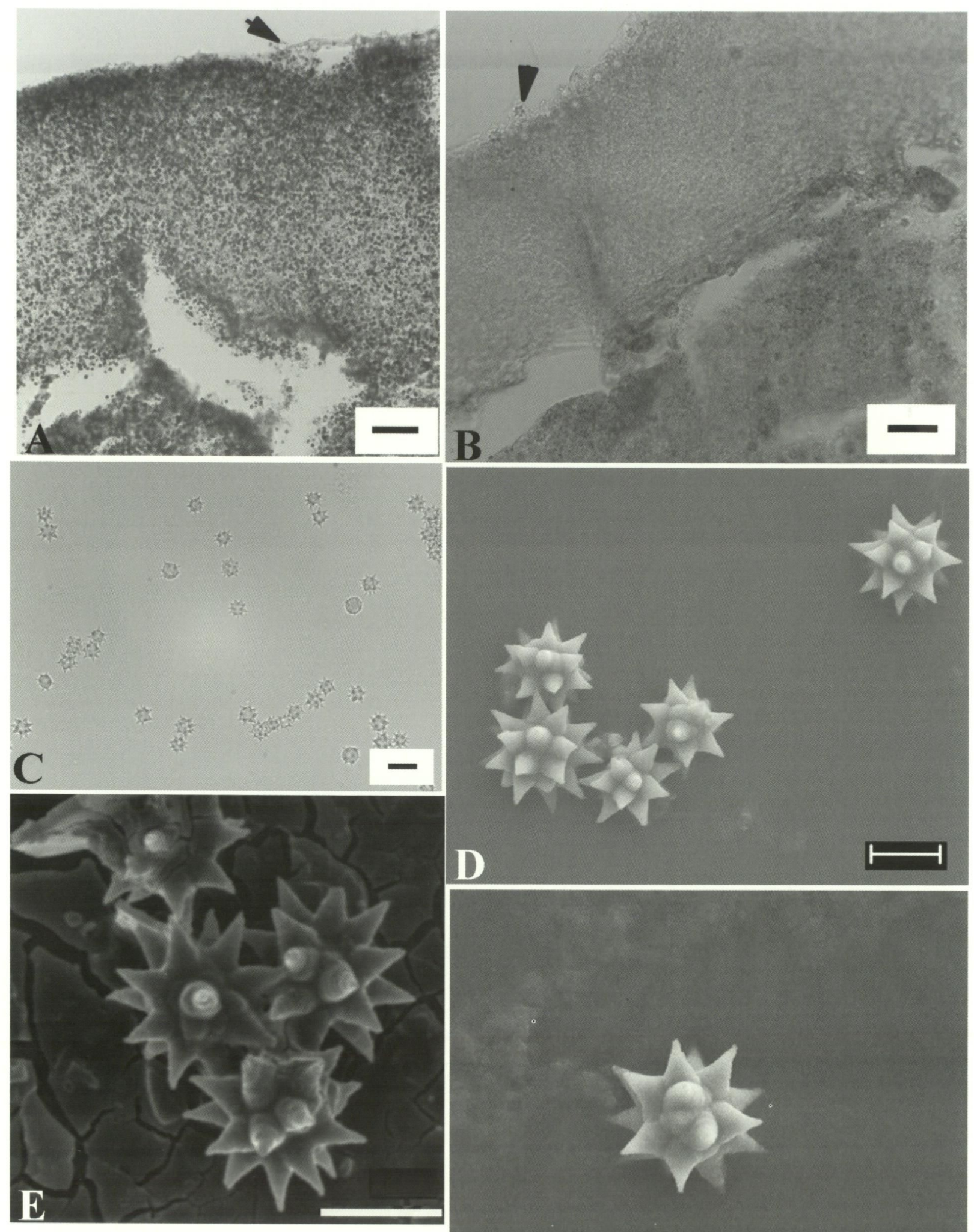

D
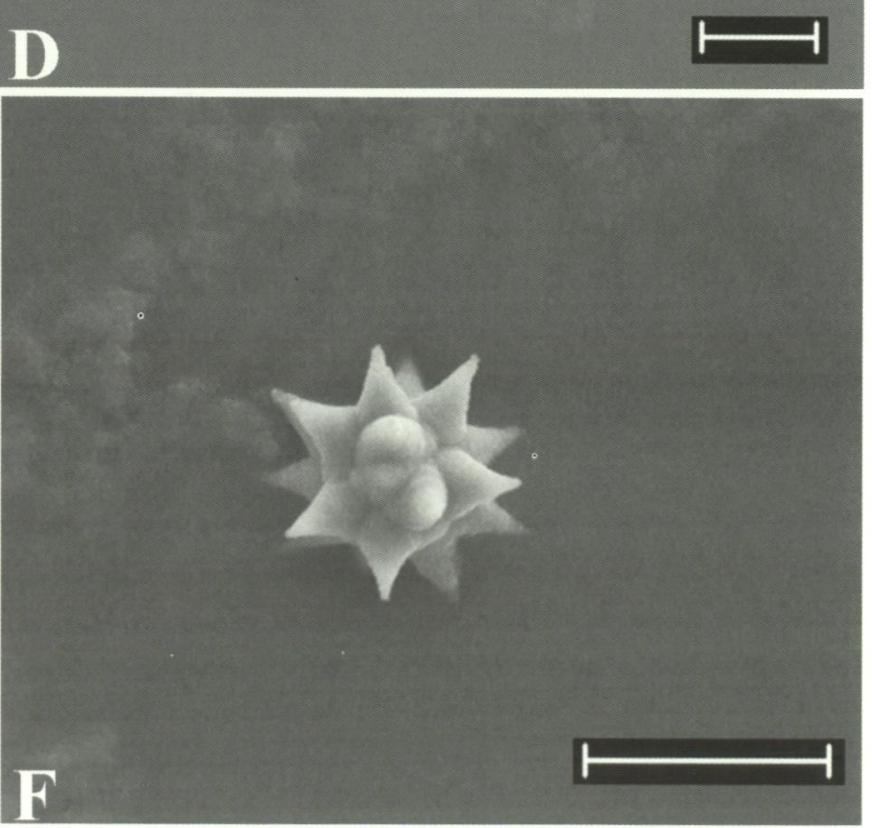

Figure 2 Internal organisation and spicules of Chondrilla linnaei. A. Internal organisation of the holotype (WAM Z13267), scale bar $=50 \mu \mathrm{m}$, spicules indicated by arrow. B. Internal organisation of a paratype (WAM Z13276) scale bar $=50 \mu \mathrm{m}$, spicules indicated by arrow. C. Spicules of the holotype (WAM Z13267), scale bar $=20 \mu \mathrm{m}$. D. SEM image of spicules of the holotype (WAM Z13267), scale bar $=10 \mu \mathrm{m}$. E. SEM image of spicules of a paratype (WAM Z13275), scale bar $=10 \mu \mathrm{m}$. F. SEM image of spicules of $C$. nucula, $($ LMJG 15108/0), scale bar $=20 \mu \mathrm{m}$. 
Table 1 Spicule dimensions of Chondrilla linnaei, Chondrilla nucula and Chondrilla sp. ${ }^{1}$

\begin{tabular}{|c|c|c|c|c|c|c|c|c|c|c|c|c|c|}
\hline \multicolumn{8}{|c|}{ Chondrilla linnaei } & \multicolumn{5}{|c|}{ Chondrilla nucula } & \multirow{2}{*}{$\begin{array}{c}\text { Chondrilla sp. } \\
\text { BMNH } \\
1948.8 .6 .55\end{array}$} \\
\hline & $\begin{array}{c}\text { BMNH } \\
\text { 1925.11.1.1331 }\end{array}$ & $\begin{array}{l}\text { SAM } \\
\text { S1106 }\end{array}$ & $\begin{array}{c}\text { WAM } \\
\text { Z13275 }\end{array}$ & $\begin{array}{c}\text { WAM } \\
\text { Z13267 }\end{array}$ & $\begin{array}{l}\text { WAM } \\
\text { Z13256 }\end{array}$ & $\begin{array}{l}\text { WAM } \\
\text { Z13259 }\end{array}$ & $\begin{array}{c}\text { WAM } \\
\text { Z31397 }\end{array}$ & $\begin{array}{c}\text { BMNH } \\
1867.7 .26 .1\end{array}$ & $\begin{array}{c}\text { LMJG } \\
15687 / 0\end{array}$ & $\begin{array}{c}\text { LMJG } \\
15108 / 0\end{array}$ & $\begin{array}{l}\text { WAM } \\
\text { Z13261 }\end{array}$ & $\begin{array}{l}\text { WAM } \\
\text { Z13268 }\end{array}$ & \\
\hline & 20 & 15 & 18 & 20 & 18 & 18 & 18 & 30 & 25 & 28 & 25 & 25 & 20 \\
\hline & 18 & 20 & 18 & 18 & 15 & 13 & 18 & 35 & 25 & 25 & 28 & 25 & 28 \\
\hline & 18 & 20 & 18 & 15 & 18 & 15 & 18 & 33 & 25 & 28 & 28 & 28 & 25 \\
\hline & 18 & 15 & 20 & 15 & 15 & 15 & 18 & 25 & 30 & 28 & 25 & 25 & 20 \\
\hline & 15 & 20 & 20 & 18 & 15 & 13 & 15 & 30 & 25 & 28 & 25 & 13 & 25 \\
\hline & 20 & 18 & 18 & 18 & 18 & 18 & 18 & 35 & 25 & 23 & 25 & 23 & 20 \\
\hline & 20 & 20 & 18 & 18 & 20 & 15 & 15 & 33 & 23 & 30 & 25 & 23 & 23 \\
\hline & 18 & 18 & 18 & 18 & 18 & 18 & 15 & 35 & 25 & 25 & 25 & 28 & 23 \\
\hline & 18 & 20 & 20 & 18 & 18 & 15 & 18 & 28 & 25 & 25 & 23 & 30 & 20 \\
\hline & 18 & 18 & 20 & 15 & 18 & 13 & 15 & 30 & 25 & 30 & 28 & 30 & 20 \\
\hline & 18 & 15 & 20 & 20 & 18 & 15 & 18 & 35 & 25 & 25 & 25 & 25 & 23 \\
\hline & 20 & 15 & 15 & 18 & 15 & 13 & 18 & 35 & 28 & 28 & 25 & 28 & 20 \\
\hline & 18 & 18 & 18 & 18 & 18 & 15 & 18 & 30 & 28 & 25 & 28 & 30 & 25 \\
\hline & 18 & 18 & 18 & 18 & 20 & 15 & 18 & 28 & 30 & 23 & 25 & 28 & 23 \\
\hline & 20 & 18 & 20 & 18 & 18 & 18 & 18 & 33 & 28 & 28 & 25 & 28 & 23 \\
\hline & 20 & 20 & 18 & 15 & 18 & 18 & 20 & 30 & 25 & 28 & 25 & 25 & 23 \\
\hline & 18 & 18 & 18 & 18 & 18 & 15 & 20 & 33 & 25 & 30 & 20 & 28 & 25 \\
\hline & 18 & 15 & 20 & 18 & 18 & 15 & 20 & 28 & 25 & 30 & 23 & 30 & 30 \\
\hline & 18 & 18 & 18 & 15 & 18 & 18 & 15 & 33 & 25 & 28 & 25 & 25 & 25 \\
\hline & 15 & 18 & 15 & 20 & 18 & 18 & 20 & 25 & 25 & 25 & 25 & 25 & 20 \\
\hline Mean & 18.3 & 17.9 & 18.4 & 17.6 & 17.6 & 15.7 & 17.7 & 31.2 & 25.9 & 27.0 & 25.2 & 26.1 & 23.1 \\
\hline SD & 1.5 & 1.9 & 1.5 & 1.7 & 1.5 & 1.9 & 1.8 & 3.3 & 1.9 & 2.3 & 1.9 & 3.9 & 2.9 \\
\hline Range & $15-20$ & $15-20$ & $15-20$ & $15-20$ & $15-20$ & $13-18$ & $15-20$ & $25-35$ & $23-30$ & $23-30$ & $20-28$ & $13-30$ & $20-30$ \\
\hline
\end{tabular}




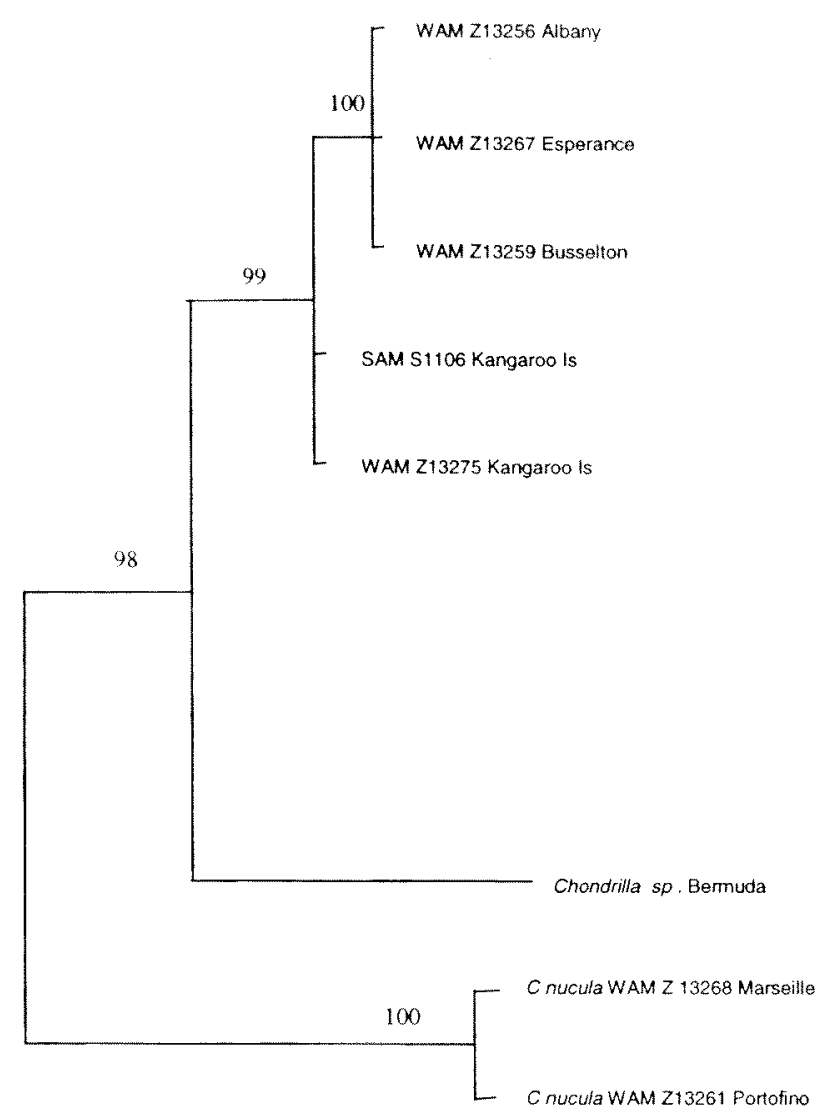

0.1

Figure 3 Phylogenetic tree of Chondrilla linnaei specimens produced with MrBayes, using the C2D2 region of $285 \mathrm{DDNA}$. Confidence levels are given at nodes. Scale bar $=0.1$ substitutions per site.

$(n=20)$ (Table 1). Molecular results from this specimen showed it to be distinct from $C$. macula $(91.1 \%$ similarity) and C. limati $(91.5 \%$ similarity to the $C$. limnat holotype), and we suggest it is another new species of Chondrilla awaiting formal description. Chontrilla manta, C. limaci and Chondrilla sp. from Bermuda all formed a cluster in the C2D2 and ITS phylogenetic analyses (although the Bermuda sample was not included in the ITS tree, Usher if al. 2004a) and all have the same spicule complement, although spicule size is distinctive and geographic separation is very large (Figure 3).

Kumar (1925) described Chomdrilla kilakaria from south India with oxysphaerasters as the only spicule type. This is a very thin encrusting species from tropical coral reefs. Chondrilla kilakatia differs from C. limaei in having a thin encrusting growth form, a tropical habit and larger oxysphaerasters (20-24 $\mu \mathrm{m}$ compared to the mean size of 17.6 $\mu \mathrm{m}$ for C. limmei). This is the only other species of Chondrilla with oxysphaerasters as the only spicule type to have been described from the Indian Ocean.

The rDNA sequences of Western Australian specimens of $\mathrm{C}$. Imnaci were $100 \%$ similar to each other. The two South Australian specimens had $97.7 \%$ similarity to the Western Australian specimens. However, as 5 of the 8 "mismatches" in these sequences included uncertain base pairs, the true sequence similarity may be higher. Alternatively, Kangaroo Island (South Australia) and Esperance (Western Australia) are separated by an approximate distance of $1600 \mathrm{~km}$ around the coastline of the Great Australian Bight (Figure 4) and it is possible that speciation is occurring between these populations.

\section{Distribution and habitat}

Chondrilla limati is found in Tasmania and South Australia, and in south Western Australia as far north as Jurien Bay (Figure 4). It is a temperate species occurring on heavily shaded rock faces, under jetties and in caves at depths less than $15 \mathrm{~m}$ (Usher et al. 2004a). This species is rare.

\section{Etymology}

Named in honour of Carolus Linnaeus and the $250^{\text {th }}$ anniversary of the publication of Systema Naturae.

\section{Chondrilla secunda Lendenfeld 1885}

Figures $1 c-d, 4-5$

Chondrilla secunda Lendenfeld 1885: 15, plate 4, figures 10-12; Hooper and Wiedenmayer 1994: 125.

\section{Material examined}

Lectotype

Australia: Victoria: piece of a specimen and four slides, Port Phillip Bay ca. $38^{\circ} 09^{\prime} \mathrm{S}, 144^{\circ} \mathrm{E}$ (ZMB Por 1131).

\section{Paralectotypes}

Australia: Victoria: three slides, Port Phillip Bay, ca. $38^{\circ} 09^{\prime} \mathrm{S}, 14452 \mathrm{E}$ (BMNH 86.6.7.95, BMNH 86.6.7.96, BMNH 1954.2.10.15).

\section{Other material examined}

Australia: Western Australia: 2 pieces, Cape Le Grande, Esperance, $34^{\circ} 01^{\prime} \mathrm{S}, 12207 \mathrm{E}, 6.4 \mathrm{~m}$ depth, K. Usher, SCUBA, 2 May 2001 (WAM Z13264); 2 pieces, Two People's Bay, Albany, 3457'S, $11811 \mathrm{E}$, $11.2 \mathrm{~m}$ depth, K. Usher, SCUBA, 8 May 2001 (WAM 213262); 2 pieces, in cave, Mistaken Island, Albany, $3503 \mathrm{~S}, 11758 \mathrm{E}, 6.2 \mathrm{~m}$ depth, $\mathrm{K}$. Usher, SCUBA, 


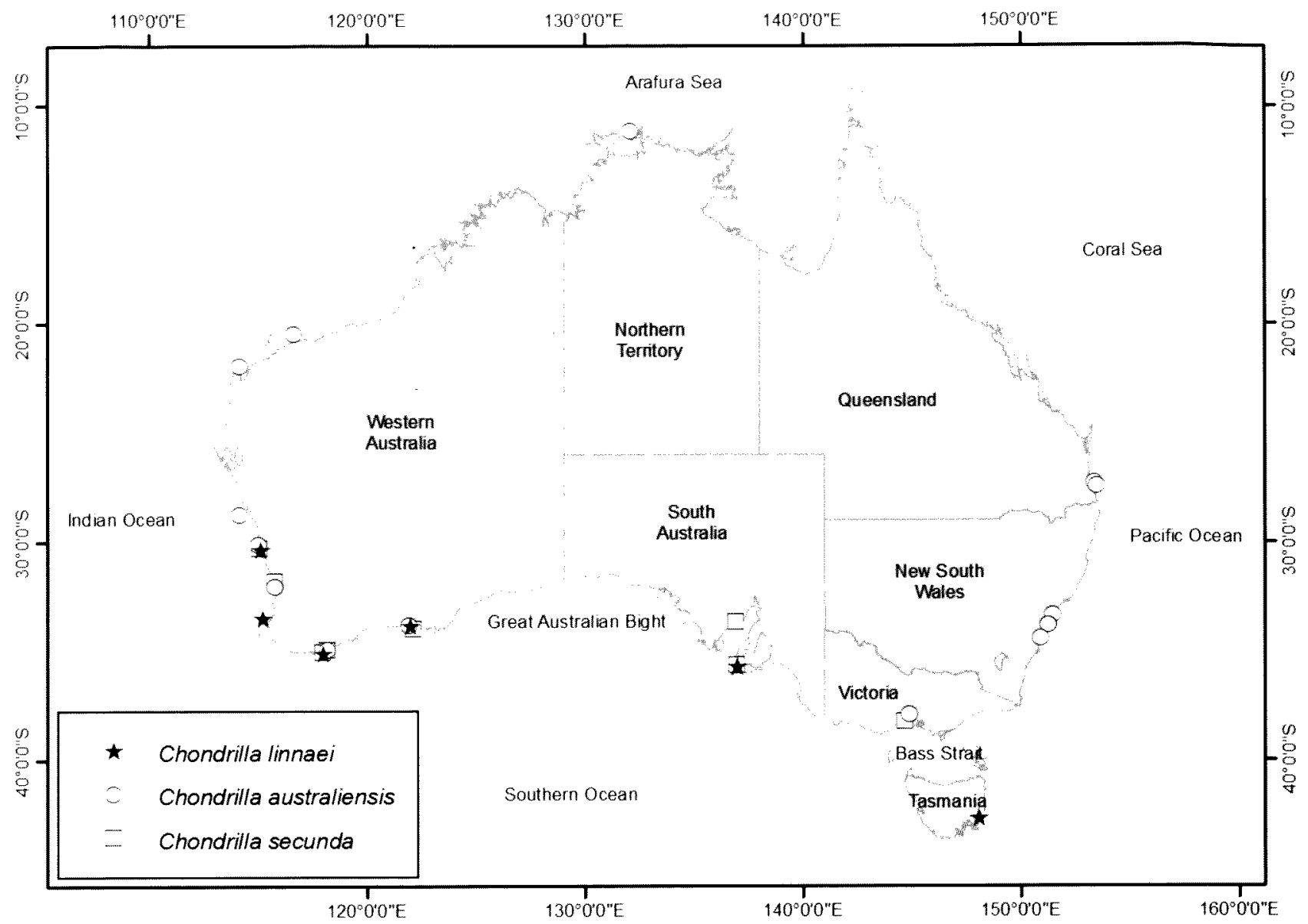

Figure 4 Map of distributions of Australian species of Chondrilla.

6 May 2001 (WAM Z13270); 1 specimen, Mistaken Island, Albany, $35^{\circ} 03^{\prime} \mathrm{S}, 117^{\circ} 58^{\prime} \mathrm{E}, 2.3 \mathrm{~m}$ depth, $\mathrm{K}$. Usher, SCUBA, 6 May 2001. (AM Z.6973 ex WAM Z13271); 1 specimen, in cave, Two People's Bay, Albany, 3457'S, $118^{\circ} 11^{\prime} \mathrm{E}, 20.5 \mathrm{~m}$ depth, K. Usher, SCUBA, 5 May 2001 (BMNH 2008.9.15.1 ex WAM Z13273); 1 specimen, station SC18, Marmion Lagoon, 31 50'S, $115^{\circ} 45^{\prime} \mathrm{E}, 4-10 \mathrm{~m}$ depth, collector L. McQuillan, SCUBA, 31 October 1999 (WAM Z12501); 2 pieces, station JWAM05, transect 3, Booka Rocks, Jurien, $30^{\circ} 17.85^{\prime} \mathrm{S}, 115^{\circ} 01.17^{\prime} \mathrm{E}, 7 \mathrm{~m}$ depth, J. Fromont, SCUBA, 28 April 2005 (WAM Z31396). Victoria: 2 pieces, Cottage by the Sea, Queenscliff, $38^{\circ} 16^{\prime} \mathrm{S}, 144^{\circ} 40^{\prime} \mathrm{E}, 5.4 \mathrm{~m}$ depth, collector K. Usher, SCUBA, 15 November 2001 (NMV F157468, exWAM Z13260). South Australia: 1 specimen, Western River Cove, Kangaroo Island, $35^{\circ} 40^{\prime} \mathrm{S}, 136^{\circ} 57^{\prime} \mathrm{E}, 3-11 \mathrm{~m}$ depth, K. Usher, SCUBA, 8 November 2001 (SAM S1107, exWAM Z13274); 1 specimen, prawn trawl out of Cowell, Spencer Gulf, ca. $33^{\circ} 41^{\prime} \mathrm{S}, 136^{\circ} 55^{\prime} \mathrm{E} 40 \mathrm{~m}$ depth, 16 April 1982, B. Mills (NTM Z1619).

\section{Diagnosis}

Chondrilla secunda is characterised by a thick spreading, encrusting growth form, an irregular undulating surface coarsely mottled in various shades of brown with a lighter interior, and 2 size classes of oxysphaerasters as the only spicule type. Diameter of large oxysphaerasters ranges from 30-100 $\mu \mathrm{m}$ (mean $65.4 \mu \mathrm{m}, \mathrm{n}=280$ ), and the small oxysphaerasters range from $15-30 \mu \mathrm{m}$ in diameter (mean $23.3 \mu \mathrm{m}, \mathrm{n}=280$ ). Density of spicules and specimen colour varies among specimens.

\section{Description}

Habitus as in Figure 1c, d. Thickly encrusting with a smooth, shiny surface. Individuals tend to form thick spreading encrustations up to $19 \mathrm{~mm}$ high with small and generally apical oscules less than $1 \mathrm{~mm}$ wide in preserved sponges. Oscules may have slightly raised rims up to $0.5 \mathrm{~mm}$ in height. Holotype specimen is a thick section of an individual $50 \mathrm{~mm}$ long by $12 \mathrm{~mm}$ high and $3 \mathrm{~mm}$ thick. Texture: Stiff alive, and firm and slightly compressible after preservation. Sponges have a dense compact interior with fine internal canals. Colour: Coarsely mottled shades of fawn, brown to dark brown with a cream or fawn interior. Specimens vary from little differentiation in pigmentation between the choanosome and ectosome (WAM Z31396) to dense pigmentation 

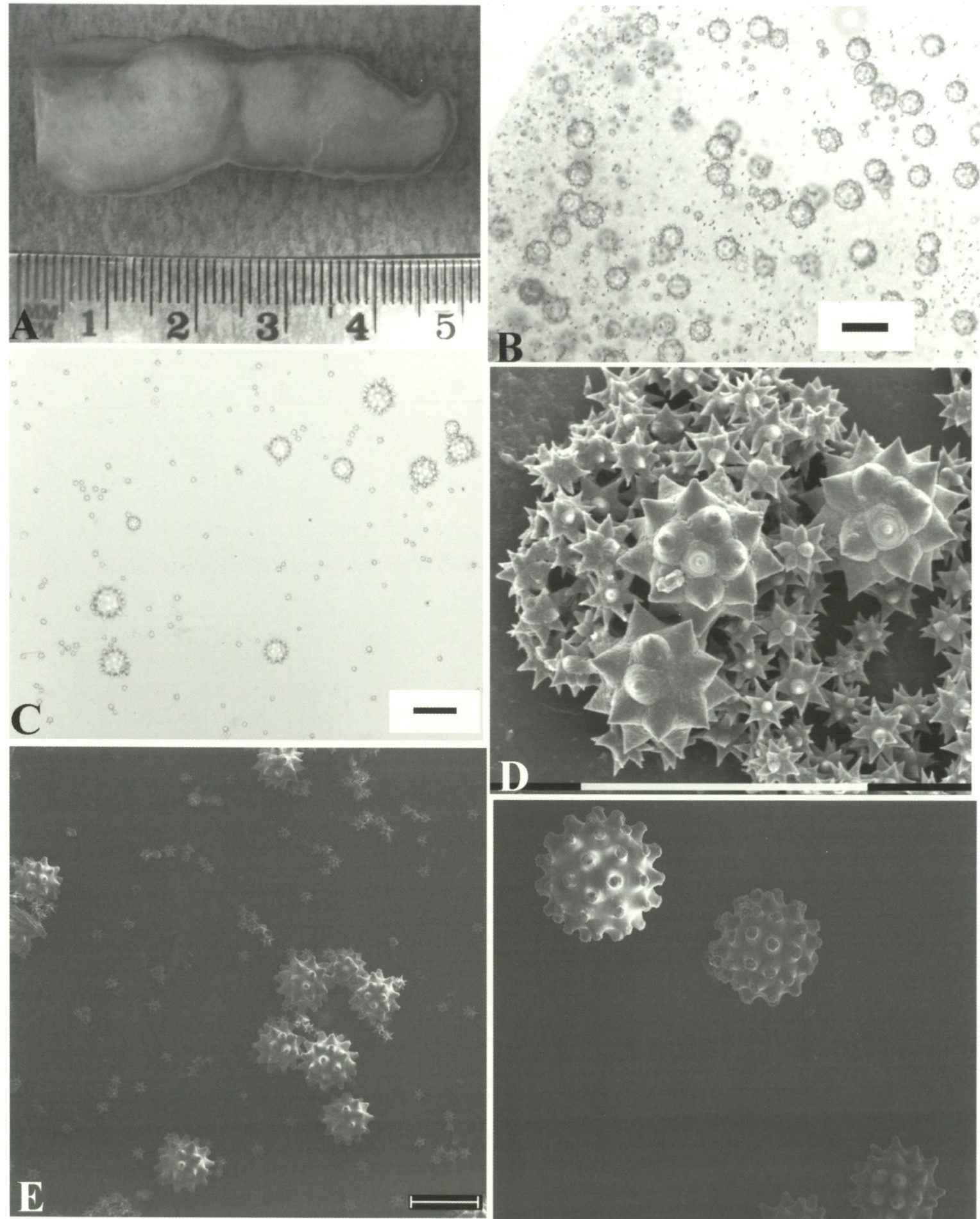

Figure 5 Type material, internal organisation and spicules of Chondrilla secunda. A. Lectotype fragment ZMB Por 1131. B. Thick section slide of ZMB Por 1131, scale bar $=100 \mu \mathrm{m}$. C. Spicules of WAM Z13262, scale bar $=100 \mu \mathrm{m}$. D. SEM image of spicules of NMVF157468, scale bar $=100 \mu \mathrm{m}$. E. SEM image of spicules of WAM Z13262, scale bar $=100 \mu \mathrm{m}$. F. SEM image of spicules of C. grandistellata (ZMB Por 3167), scale bar $=100 \mu \mathrm{m}$.

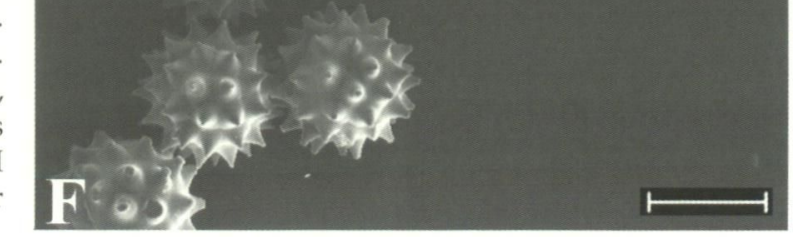


towards the surface and around internal canals. Degree of pigmentation varies among specimens.

General organisation: (Figure 5a, b). Ectosome: large oxysphaerasters common throughout. This region varies in thickness from $140-800 \mu \mathrm{m}$, frequently with a narrow outer strongly pigmented layer 50-150 $\mu \mathrm{m}$ thick. In the type material ZMB Por 1131 the two sizes of oxysphaerasters are equally abundant in the ectosome. In recently collected specimens the ectosome may contain more small oxysphaerasters than large (e.g. WAM Z13260, WAM Z13270). Occasionally the ectosome is barely differentiated from the choanosome, and has no additional pigmentation to differentiate it (WAM Z13273). Choanosome: The interior is dense and compact with fine canals, but less so than the ectosome. Both types of oxysphaeraster are more dense around internal canals. WAM Z13264 has a basal layer of both sizes of oxysphaerasters.

Spicules: (Figure 5c-e). Two types of oxysphaeraster. Oxysphaerasters: large, either conical with faintly mammillate ray tips or with flattened, faintly spined 'mesa-topped' rays. These spicules are very variable in size, with the diameter from ray tip to opposing ray tip ranging from 30-100 $\mu \mathrm{m}$ (mean $65.4 \mu \mathrm{m}, \mathrm{n}=280$ ). Oxysphaerasters: small, consistently tapered, conical rays extending from a large central disc. These spicules have a size range of $15-30 \mu \mathrm{m}$ in diameter (mean 23.3 $\mu \mathrm{m}, \mathrm{n}=280$ ) (Table 2).

Cyanobacteria: sponges were found to contain cyanobacteria in low concentrations with $99.8 \%$ partial sequence similarity to Symechococcus WH 8103 (Genbank), a species which occurs in the water column (Usher et al. 2004c).

\section{Remarks}

Chondrilla secunda has not been reported since its first description in Lendenfeld, 1885. Our collection of this species has extended its geographical range from the type locality in Port Phillip Bay, Victoria to the mid west coast of Western Australia. It has also enabled a thorough redescription of the species including field characters.

We discovered that the only extant type specimen of this species is a piece three $\mathrm{mm}$ thick with four associated microscope slides all labeled ZMB Por 1131, and lodged in the Museum für Naturkunde, Berlin. We have designated this syntype material to be the lectotype of the species. All the syntype specimens of Chondrilla secunda Lendenfeld 1885 from the Natural History Museum and the Australian Museum (AM G9057, BMNH 1886.6.7.92, BMNH 1886.6.7.9394) were examined and found to be specimens of $C$. australiensis or other non-related species (BMNH 1886.6.7.92 is a lithistid). The only type material remaining of this species in the Natural History Museum are three historic slides (BMNH 1886.6.7.95-96 and BMNH 1954.2.10.15) we have designated paralectotypes of this species. We examined slides (ZMB 650) previously thought to be syntype material (Hooper and Wiedenmayer 1994) and they are not $C$. secunda. We have distributed recently collected specimens of this species to the Museum of Victoria, South Australian Museum, Australian Museum, Natural History Museum and Western Australian Museum to assist future studies on this species.

The density of spicules, and the relative proportions of the large and small oxysphaerasters in the choanosome and ectosome of $C$. secunda varies among specimens. The cortical region of this species is less pronounced than in C. linnaei but more pronounced than in C. australiensis. This species is consistently thicker than $C$. australiensis and with a more irregular undulating surface, and a more mottled, less finely speckled appearance than C. linnaei. In some specimens (e.g. SAM S1107) the two size categories of oxysphaeraster grade into each other (Table 2). However, the morphology of the oxysphaerasters differs, with the small size category having consistently long, thin conical rays, and the large size category having short, thick conical, mammillate or mesatopped rays.

Three species of Chondrilla have been described with large oxysphaerasters: Chondrilla secunda from southern Australia, C. sacciformis Carter 1879 from Mauritius and C. grandistellata Thiele 1900 from Indonesia (Ternate).

Chondrilla grandistellata was synonymised with C. sacciformis by Dendy (1916). The type specimen of C. sacciformis from the Natural History Museum, London (BMNH 95.8.9.2) had oxeas as well as sphaerasters. Carter mentioned both spicule categories in the type description (Carter 1879, p. 299), so this is likely to be the true type of the species, but oxeas are not a spicule type ever reported in the genus Chondrilla. The sphaerasters in the specimen BMNH 95.8.9.2 are more like sterrasters in form, and this species may need to be reassigned to the family Geodiidae. Dendy (1916, P. 245) examined teased fragments mounted in balsam and a spicule preparation (presumably made by Carter), and in the absence of oxeas concluded that $C$. sacciformis was a good species of Chondrilla. We suggest that the latter preparations are compared to the type specimen and a final conclusion made as to whether $C$. sacciformis is a valid species of Chondrilla.

The type specimen of Chondrilla grandistellata (ZMB Por 3167) and a second specimen (ZMB Por 3007 ) have large mesa-shaped oxysphaerasters with a mean diameter of $140 \mu \mathrm{m}(\mathrm{n}=20)$ 


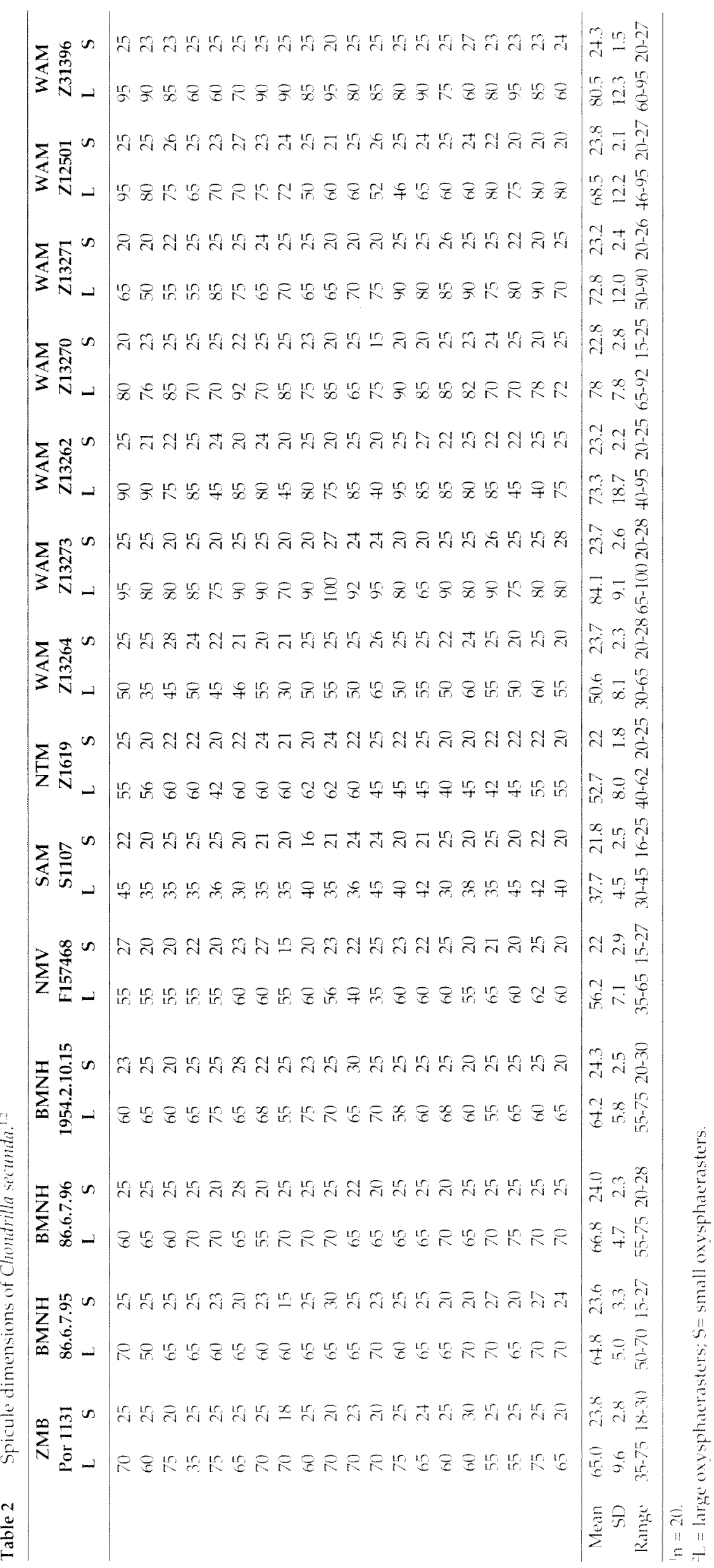


and occasional smaller (35-45 $\mu \mathrm{m}$ diameter) identical forms, possibly developmental in nature (Figure 5f, Table 2). This species has larger oxysphaerasters than $C$. secunda (mean diameter $65.4 \mu \mathrm{m})$, and does not have the second smaller and morphologically distinct oxysphaeraster seen in C. secunda. Sequence data for these specimens could not be obtained, but a large geographical disjunction occurs between the tropical $C$. grandistellata (Indonesia) and the temperate $C$. secunda (south coast of Australia), as well as the differences in spicule sizes and morphologies, therefore we consider $C$. secunda to be a valid temperate species.

Sequencing of rDNA of nine specimens of Chondrilla secunda showed close molecular similarity between all specimens (Usher et al. $2004 a$ ), with up to $99.5 \%$ sequence identity.

\section{Distribution and habitat}

Chondrilla secunda is found in Victoria, South Australia, and south Western Australia as far north as Jurien Bay (Figure 4). It is a temperate species occurring on heavily shaded rock faces at depths less than $15 \mathrm{~m}$ (Usher et al. 2004a). This species is uncommon. Specimen NMV F157468 from Queenscliff, Victoria collected on the $15^{\text {th }}$ November 2001 at $5.4 \mathrm{~m}$ depth has synchronously developing spermatocysts $33 \mu \mathrm{m}$ wide.

\section{Chondrilla australiensis Carter 1873}

Figures 1, 4, 6

Chondrilla australiensis Carter 1873: 23, plate I, figures 10-14, 16; Lendenfeld 1885: 15.

Chondrilla corticata Lendenfeld 1885: 18, plate 4, figures 18-20, plate 5, figure 17; Hooper and Wiedenmayer 1994: 123.

Chondrilla papillata Lendenfeld 1885: 17, plate 5, figures 13-16; Hooper and Wiedenmayer 1994: 123.

\section{Material examined}

Holotype of Chondrilla australiensis

Australia: New South Wales: Port Jackson, ca. $33^{\circ} 51^{\prime} \mathrm{S}, 151^{\circ} 16^{\prime} \mathrm{E}$ (BMNH 1895.8.9.1).

\section{Syntype of $\mathrm{C}$. corticata}

Australia: New South Wales: Port Jackson, ca. $33^{\circ} 51^{\prime} \mathrm{S}, 151^{\circ} 16^{\prime} \mathrm{E}$ (AM G9050).

\section{Syntype of C. papillata}

Australia: New South Wales: Port Jackson, ca. $33^{\circ} 51^{\prime} \mathrm{S}, 151^{\circ} 16^{\prime} \mathrm{E}$ (AM G9051)

\section{Other material examined}

Australia: Northern Territory: 1 specimen, Coral Bay, Point Essington, $11^{\circ} 11^{\prime}$ S, $132^{\circ} 03^{\prime} \mathrm{E},<1$ $\mathrm{m}$ depth, collector J.N.A. Hooper and A.J. Bruce, snorkel, 19 July 1981 (NTM Z377). Queensland: 2 pieces, Roby Bay, Moreton Bay, $27^{\circ} 18^{\prime} \mathrm{S}, 153^{\circ} 22^{\prime} \mathrm{E}$, $<1 \mathrm{~m}$ depth, collector S. Cook, 7 June 2001 (WAM Z13269); 2 pieces, Point Lookout, North Stradbroke Island, $27^{\circ} 28^{\prime} \mathrm{S}, 153^{\circ} 28^{\prime} \mathrm{E}$, < $1 \mathrm{~m}$ depth, collector S. Cook, 2 June 2001 (WAM Z13263). New South Wales: 3 pieces, Bateau Bay, Central Coast, $33^{\circ} 23^{\prime} \mathrm{S}, 151^{\circ} 29^{\prime} \mathrm{E}$, intertidal, collector J. Fromont \& D. Sutton, 5 January 2001 (WAM Z13254); 2 pieces, Flinders Island, Wollongong, 34 26'S, 150 53'E, 11 $m$ depth, collector A. Davis, SCUBA, 1 March 2001 (WAM Z13265). Victoria: 1 specimen, Port Phillip Bay, 37 58'S, 144 54'E (BMNH 1886.6.7.87-89). Western Australia: 2 pieces, Esperance jetty no.1, $33^{\circ} 51^{\prime} \mathrm{S}, 121^{\circ} 55^{\prime} \mathrm{E}, 10.7 \mathrm{~m}$ depth, collector K. Usher, SCUBA, 1 May 2001 (WAM Z13266); 4 pieces, Two People's Bay, Albany, 34 $57^{\prime} \mathrm{S}, 118^{\circ} 11^{\prime} \mathrm{E}, 5.3 \mathrm{~m}$ depth, collector K. Usher, SCUBA, 8 March 2001 (WAM Z13272); 1 specimen, South Mole, Fremantle, $32^{\circ} 03^{\prime} \mathrm{S}, 115^{\circ} 45^{\prime} \mathrm{E}, 4-10 \mathrm{~m}$ depth, collector $\mathrm{K}$. Usher SCUBA, 31 October 1999 (WAM Z13257); 1 specimen, South Mole, Fremantle, $32^{\circ} 03^{\prime} S$, $115^{\circ} 45^{\prime} \mathrm{E}, 4-10 \mathrm{~m}$ depth, collector $\mathrm{K}$. Usher SCUBA, 31 October 1999 (WAM Z13255); 1 specimen, station JWAM13, transect 1, Julia Rocks, Jurien, 30 09.36'S, $114^{\circ} 59.72^{\prime} \mathrm{E}, 2.5-4.7 \mathrm{~m}$ depth, collector J. Fromont SCUBA, 3 May 2005 (WAM Z31393); 1 specimen, Mid-reef, Houtman Abrolhos, $28^{\circ} 46^{\prime} \mathrm{S}$, $114^{\circ} 08^{\prime} \mathrm{E}, 24.8 \mathrm{~m}$ depth, collector $\mathrm{K}$. Usher, SCUBA, 7 May 2000 (WAM Z13257); 1 fragment, Outer reef, Exmouth, 21 ${ }^{\circ} 57^{\prime} \mathrm{S}, 114^{\circ} 07^{\prime} \mathrm{E}, 9.8 \mathrm{~m}$ depth, collector K. Usher, SCUBA, 15 May 2001 (WAM Z13278); 1 specimen, station DA3/99/42, Georgeff Reef, Dampier Archipelago, 2029.34'S, $116^{\circ} 36.80^{\prime} \mathrm{E}$, intertidal, collector J. Fromont, 28 August 1999 (WAM Z5419).

\section{Diagnosis}

Characterised by forming thin encrusting sheets that vary greatly in size. Colour varies from maroon to ochre exterior with a cream interior. Spicule complement of oxysphaerasters (diameter range 16-38 $\mu \mathrm{m}$, mean $25.9 \mu \mathrm{m}, \mathrm{n}=360$ ) and oxyasters (diameter range 15-35 $\mu \mathrm{m}$, mean 23.8 $\mu \mathrm{m}, \mathrm{n}=360$ ).

\section{Description}

Habitus as in Figure 1e, f. Encrusting sponge of variable thickness 0.2 to $3.0 \mathrm{~cm}$ at thickest dimension. Individuals may form small encrusting patches to extensive spreading mats up to $1 \mathrm{~m}$ across. Oscules occur on the upper surface and are closed or very small (300 $\mu \mathrm{m}$ wide) in the preserved state. They can occur on low raised lobes $5 \mathrm{~mm}$ in height with slightly raised rims up 

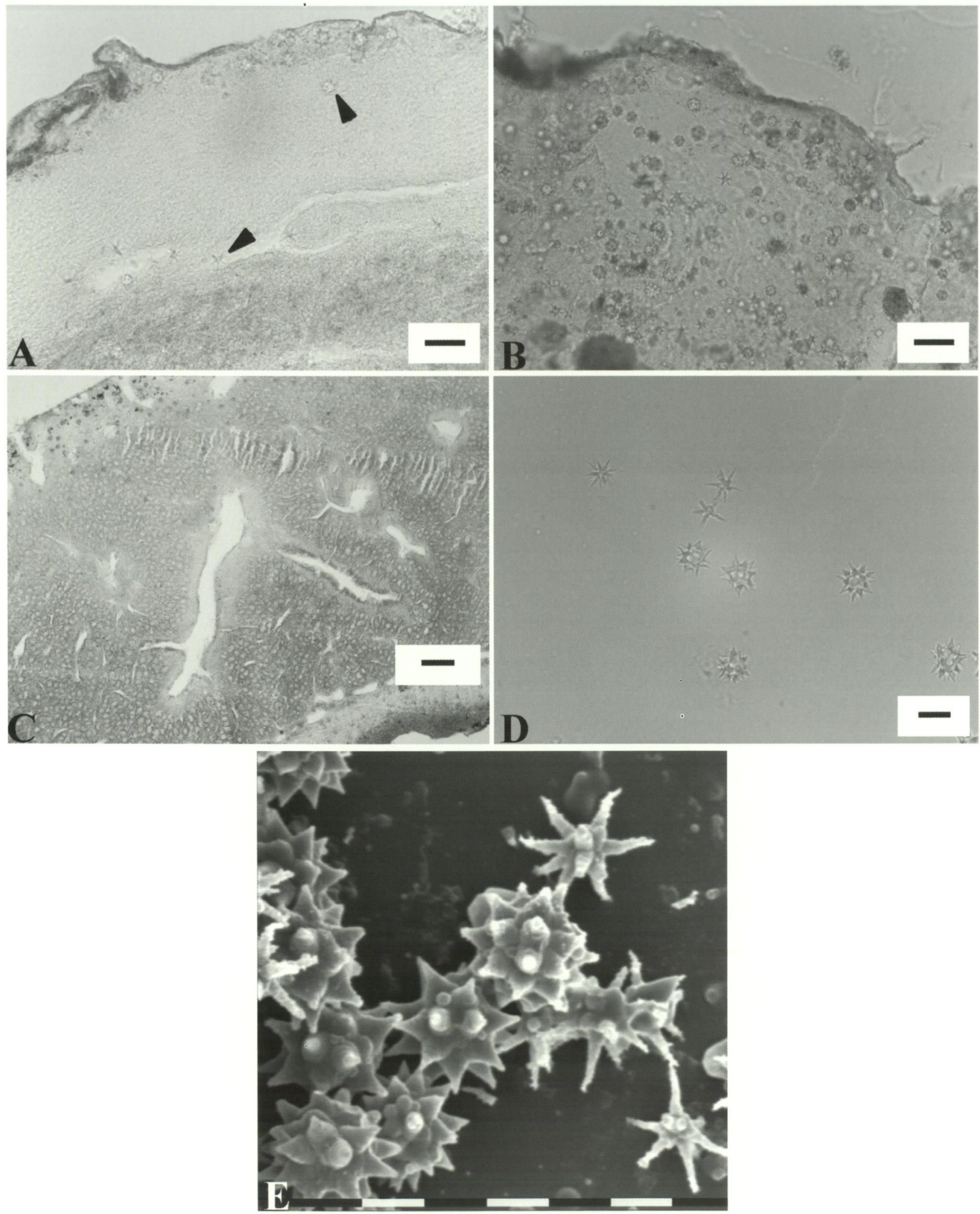

Figure 6 Internal organisation and spicules of Chondrilla australiensis. A. Internal organisation of the holotype (BMNH 1895.8.9.1), scale bar $=50 \mu \mathrm{m}$, spicules indicated by arrows. B. Internal organisation of the holotype (AM G9051) of C. papillata, scale bar $=50 \mu \mathrm{m}$. C. Internal organisation of WAM Z13266, scale bar $=200 \mu \mathrm{m}$. D. Spicules of WAM Z13266, scale bar $=20 \mu \mathrm{m}$. E. SEM image of spicules of WAM Z13254, scale bar $=10 \mu \mathrm{m}$. 
to $1 \mathrm{~mm}$ high. The surface is shiny and slippery. Texture: Collagenous, compressible but not elastic. The interior is dense and compact with fine vertical canals throughout. Colour: Variable from chocolate brown to ochre or maroon. Surface colour is more homogenous in C. australiensis than in the other Chondrilla species occurring in Australia. Specimens in high light tend to be ochre and those in shade are maroon. Sides of sponges can be cream.

General organisation: (Figure 6a-c). Ectosome: Thin superficial layer 5-15 $\mu \mathrm{m}$ wide, usually more densely pigmented than the interior. Less pigmented layer of ectosome beneath is $110-270$ $\mu \mathrm{m}$ thick. Spicules variable in this region, with some specimens including the holotype having sparse spicules. In the syntypes of $C$. corticata and $C$. papillata oxysphaerasters are dense in this region. Choanosome: The interior is differentiated from the ectosome in colour and density of the mesohyl. Spicules can be sparse in this region but are more dense around the edges of canals, or oxysphaerasters are dispersed evenly, or both oxysphaerasters and oxyasters are dense. In most specimens oxysphaerasters are the dominant spicule but in some the oxyasters are common or dominate, particularly lining the edges of canals (e.g. WAM Z13254 and Z13265). Some specimens have a basal layer of oxysphaerasters $150-400 \mu \mathrm{m}$ thick (WAM Z13266, Z13258).

Spicules: (Figure 6d, e). Small oxysphaerasters with short thick rays tapering abruptly to points, or occasionally mammillate (diameter range $16-38$ $\mu \mathrm{m}$, mean $25.9 \mu \mathrm{m}, \mathrm{n}=360$ ). Small oxyasters with tapering microspined rays frequently bi- or multirayed and irregularly bent (diameter range 15-35 $\mu \mathrm{m}$, mean $23.8 \mu \mathrm{m}, \mathrm{n}=360$ ) (Table 3).

Cyanobacteria: sponges were found to contain high concentrations of the unicellular cyanobacterium "Candidatus Synechococcus spongiarum" (Genbank) in surface tissues. "Candidatus S. spongiarum" was also found in samples of Chondrilla nucula from the Ligurian Sea, with the two symbionts having 100\% $16 \mathrm{~S}$ rDNA sequence similarity. This cyanobacterial species has not to date been found free-living in seawater (Usher et al. 2004c).

\section{Remarks}

Given the enormous variability in live colour, the variable distribution and abundance of the two spicule types within the skeleton, and the large geographical distribution of Chondrilla australiensis in Australia, it was extremely helpful in this study to have undertaken molecular analyses to complement the morphological analyses of this species (Usher et al. 2004a). We had previously successfully sequenced the type material (BMNH 1895.8.9.1) and 17 other specimens of $C$. australiensis. Sequence similarities between the specimens ranged from $99.1 \%$ (4 base pair differences) to $100 \%$, with most sequences only being 1 or 2 base pairs different from each other. However, the sample from Dampier typically had only $97.5 \%$ sequence similarity to other samples of C. australiensis. This species is now known from almost the entire coastline of Australia (Figure 4).

Numerous species of Chondrilla with oxysphaerasters and oxyasters as the spicule complement have been described including $C$. mixta Schulze 1877 from the Red Sea, C. distincta Schulze 1877 from the Caroline Islands, C. nuda Lendenfeld 1897 from Zanzibar, C. media Hentschel 1912 from Indonesia, and C. agglutinans Dendy 1916 from India (the latter four are all accepted as synonyms of C. mixta). Chondrilla mixta was reported from Christmas Island in the Indian Ocean by Kirkpatrick (1900). We did not examine this material and cannot determine if this species assignment is valid, or whether Kirkpatrick had found $C$. australiensis. The size of the spicules he described (oxysphaerasters $25-30 \mu \mathrm{m}$, oxyasters $24-28 \mu \mathrm{m}$ ) are within the size ranges we determined for $C$. australiensis. We attempted to collect Chondrilla from a limited number of locations at Christmas Island but were unsuccessful in finding any specimens.

Chondrilla globulifera Keller 1891 from the Red Sea and C. ternatensis Thiele 1900 from Indonesia (Ternate) are considered synonyms of C. australiensis (Burton, 1924). Chondrilla jinensis Hentschel 1912 from Indonesia is one of the few species with a spicule complement of oxysphaerasters and oxyasters to have been retained as a valid species, and it has larger spicules than $C$. mixta and $C$. australiensis (oxysphaerasters ca. 50 $\mu \mathrm{m}$ and oxyasters $\leqslant 80 \mu \mathrm{m})$.

\section{Distribution and habitat}

Chondrilla australiensis is found from the Northern Territory along the east coast of Australia to Victoria, and from south to north Western Australia. We did not find this species in South Australia, where sampling was minimal, and no collecting occurred in Tasmania. This is a widespread distribution, with specimens occurring in shallow tropical and temperate habitats from the intertidal to $30 \mathrm{~m}$ depth in both shaded and full light environments. The species is common, and is always encrusting with a highly variable extent of cover.

\section{Key to Australian species of Chondrilla*}

1. Oxyasters present........... Chondrilla australiensis 
Table 3 Spicule dimensions of Chondrilla australiensis ${ }^{1,2}$.

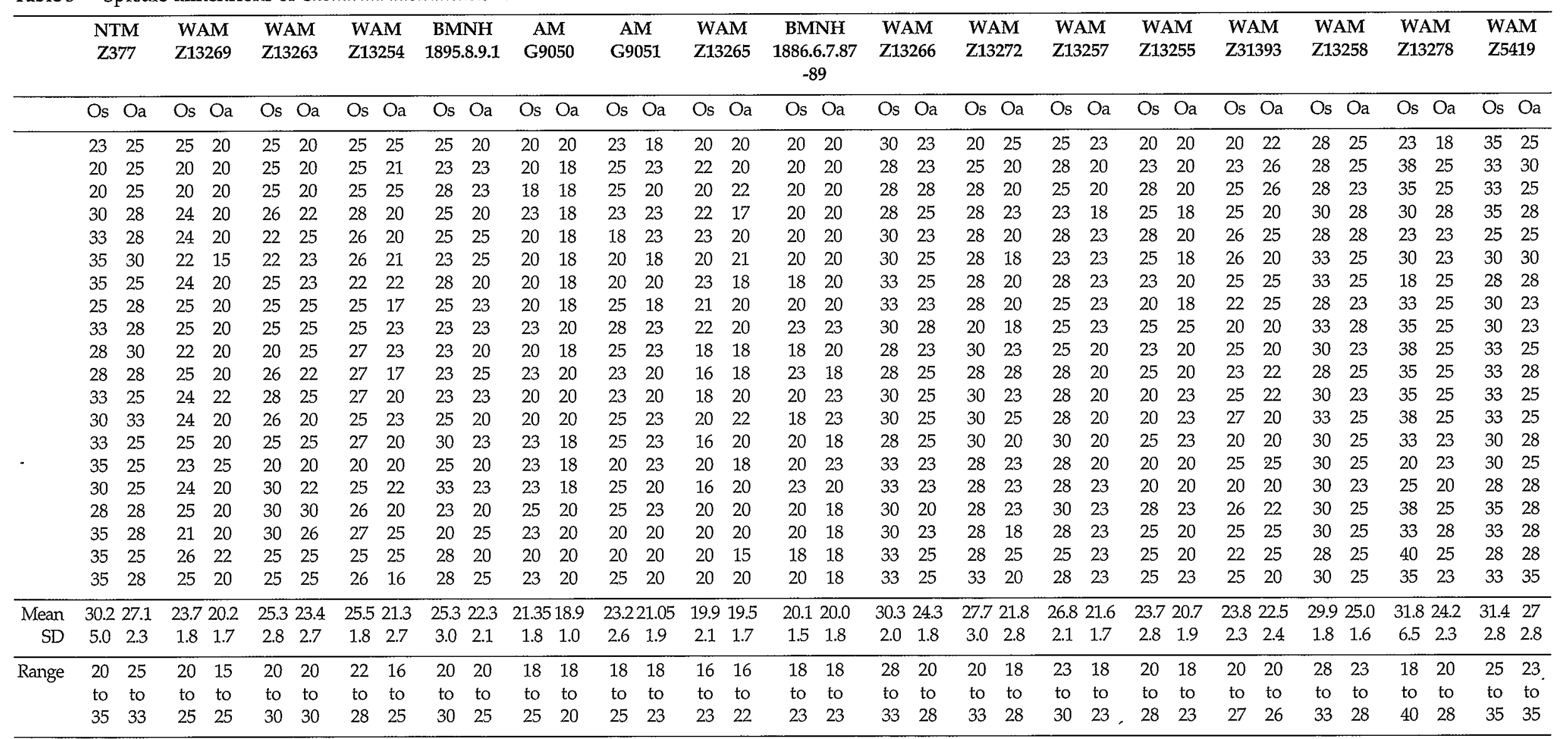

${ }^{2} \mathrm{Os}=$ oxysphaeraster, $\mathrm{Oa}=$ oxyaster. 
Oxyasters absent.

2. Oxysphaerasters present 1 small size

.Chondrilla linnaei

Oxysphaerasters present 2 sizes

Chondrilla secunda

*we have not included Chondrilla mixta in this key as it was not found in this study and its presence in Australia remains to be determined.

\section{DISCUSSION}

In this study we found three species of Chondrilla with distinctive spicule complements. Chondrilla australiensis has two spicule types; oxysphaerasters and oxyasters of similar small size. Chondrilla linnaei only has oxysphaerasters of a single small size category, while $C$. secunda has two types of oxysphaerasters, one a mammillate oxysphaeraster with a large size range and a second smaller oxysphaeraster with pointed, conical rays and a small size range. The distribution and abundance of spicules throughout the sponge body is highly variable for all three species. In most specimens spicules are abundant in the ectosome, or in the apical surface layer of the sponge and/or around internal canals, and more dispersed in the choanosome. Some specimens had a basal layer of spicules. In other specimens spicules were more evenly distributed throughout the sponge body. The most reliable morphological characters of these three species are their distinctive spicule complements and their growth forms. Chondrilla linnaei forms small discrete encrusting lobes, $C$. secunda comprises larger thick encrusting individuals and $C$. australiensis forms extensive thin encrusting mats. Neither C. linnaei nor C. secunda ever form the extensive mats common to $C$. australiensis. However, even a trained collector will have difficulty accurately differentiating these species in the field, and a spicule check will be essential.

Cavalcanti et al. (2007) recently reported very high variability in some of the common characters used in sponge taxonomy, including skeletal organization, surface morphological features and spicule sizes, and they could not distinguish cryptic species of Chondrilla on the basis of these characters. We are fortunate that the Australian species described here have distinctive spicule complements.

This morphological study of Australian Chondrilla species supports molecular data that clearly distinguished the three species using two different gene regions (Usher et al. 2004a). For the species described here, the greatest genetic distance occurred between $C$. secunda and $C$. australiensis $(85.5 \%$ and $86.1 \%$ sequence similarity for the C2D2 and ITS regions, respectively). The
$\mathrm{C} 2 \mathrm{D} 2$ sequence similarity between the holotypes of C. australiensis and C. linnaei was $89.7 \%$ and between $C$. secunda and C. linnaei $88.1 \%$. These results confirm the existence of three species. Intraspecific genetic similarity was consistently high within all three species, and confirmed the south and west coast distributions of $C$. secunda and $C$. linnaei, and the widespread, almost circumAustralian, distribution of C. australiensis.

Klautau et al. (1999) identified five distinct genetic forms within Chondrilla nucula using allozyme techniques, and found that variation in spicule size did not correlate with the boundaries defined genetically. Some of these genetic forms have recently been studied by Vilanova et al. (2007) who found that the sulphated polysaccharide content distinguished cryptic species. This technique can be used on formalin fixed, frozen and dried specimens as well as those preserved in ethanol (Vilanova et al. 2007). These results suggest that there are a number of species with almost identical spicule complements and sizes that have been found in the Caribbean Sea and south western Atlantic that would previously have been called $C$. nucula, thus erroneously contributing to the cosmopolitan distribution of this species. Instead these are new species awaiting formal description, and the distribution of C. nucula is thought to be restricted to the Adriatic and Mediterranean seas (Klautau et al. 1999). The incorporation of novel character sets is essential for the determination of species within Chondrilla and many other sponge genera with few distinguishing morphological characters.

The three Australian species occurred in sympatry along the south and west coasts of Australia. Chondrilla australiensis has the most widespread distribution including both tropical and temperate regions of Australia, while C. secunda and C. linnaei appear restricted to temperate south and west Australia. It may be that the species have temporal separation of reproductive activity. We found spermatocysts in the specimen of $C$. secunda collected from Victoria in mid November, while Usher et al. (2004b) reported sperm development occurring over two weeks in February/March in C. australiensis from Fremantle, Western Australia. If C. secunda also has short periods of sperm development (it has now been found that most sponge species do), then these species are reproducing at different times of the year. Studies on the reproduction of $C$. secunda and $C$. linnaei would progress this hypothesis.

In a recent study Usher and Ereskovsky (2005) noted that coeloblastulae larvae of Chondrilla australiensis are short lived and begin to settle after a free-swimming period of $24-36 \mathrm{~h}$. These short 
dispersion abilities are now commonly reported for sponges and may account for the short range endemism of many species. The almost circum-Australian distribution of $C$. australiensis could be explained partly by longshore currents along continuous coastline gradually dispersing larvae or asexual products. Fromont (1999) first suggested that asexual fragmentation may occur in C. australiensis, and this has been supported by Zilberberg et al. (2006) who found similar asexual products of Chondrilla species from the Caribbean and Brazilian coastline. Their study found low clonality $(7 \%)$ in a heterogeneous environment with strong upwelling, and higher clonality (39\%) in a more homogeneous and temporally stable environment. A similar study of the population genetics of Australian Chondrilla species would increase understanding of their dispersal abilities and thus their differing biogeographic distributions.

Individuals of Chondrilla australiensis have been found to contain the unicellular cyanobacterial symbiont "Candidatus Synechococcus spongiarum" (Usher et al. 2004c). These symbionts are apparently transferred to the young by vertical transmission via developing eggs and occasionally sperm (Usher et al. 2005). This symbiont was not found in C. secunda or C. linnaei, which contain symbionts with $99.8 \%$ and $99.7 \%$ partial sequence similarity, respectively, to Synechococcus WH 8103 (GenBank), a cyanobacterium from the water column (Usher et al. 2004c). Although the presence of "Candidatus Synechococcus spongiarum" distinguished $C$. australiensis from $C$. secunda and $C$. linnaei, some sponge symbionts occur in more than one species and over vast geographic distances. For example, Usher et al. 2004c found "Candidatus Synechococcus spongiarum" in samples of C. nucula from the Ligurian Sea had $100 \% 16 \mathrm{~S}$ rDNA sequence similarity to those sequenced from $C$. australiensis.

This is the third recent publication describing new species of Chondrilla. Desqueyroux-Faundez and Van Soest (1997) described a new species from the Galápagos Islands, and two new species have been described from Mexico (Carballo et al. 2003). The recent awareness of the cryptic nature of Chondrilla species (Klautau et al. 1999, Usher et al. 2004a, Vilanova et al. 2007) suggests that many more species are likely to be found.

\section{ACKNOWLEDGEMENTS}

The new species was discovered during a $\mathrm{PhD}$ research project undertaken by K.M. Usher, funded by Australian Biological Resources Study (ABRS). We thank Dr. A. Davis, University of Wollongong and S. Cook, Queensland Museum for collecting specimens, and Professor J. Vacelet,
Centre d'Océanologie de Marseille and Andrew Usher, Perth for assistance with fieldwork. Museum colleagues provided access to material and/or critical information and we thank the following for their assistance: $\mathrm{C}$. Valentine and $\mathrm{E}$. Sherlock, Natural History Museum, London; Dr. B. Alvarez, Museum and Art Gallery of the Northern Territory, Darwin; Dr. P. Berents and Dr. S. Keable, Australian Museum, Sydney; Dr. C. Lüter and Dr. K. Meschter, Museum für Naturkunde, Berlin; and Dr. R. Desqueroux-Faundez, Muséum d'histoire Naturelle, Geneva. Piers Higgs (Gaia Resources) kindly produced the map, and Oliver Gomez (Western Australian Museum) produced the light microscopy images and compiled the plates.

\section{REFERENCES}

Boury-Esnault, N. and Lopès, M.T. (1985). Les Demosponges littorales de l'Archipel des Açores. Annales de l'Institut Océanographique 61(2): 149-225.

Boury-Esnault, N. (2002). Order Chondrosida BouryEsnault and Lopès, Family Chondrillidae Gray (pp. 291-297). In: Hooper, J.N.A. and van Soest, R.W.M. (eds.), Systema Porifera: A Guide to the Classification of Sponges, volume 1. Kluwer Academic/Plenum Publishers: New York.

Burton, M. (1924). The genus Chondrilla. Annals and Magazine of Natural History (9) 14: 206-209.

Burton, M. (1934). Sponges. In: Scientific Reports of the Great Barrier Reef Expedition 1928-29, volume 4(14), 513-621, pls 1-2. British Museum (Natural History): London.

Carballo, J.L, Gómez, P. and Cruz-Barraza, J.A. and Flores-Sánchez, D.M. (2003). Sponges of the family Chondrillidae (Porifera: Demospongiae) from the Pacific coast of Mexico, with the description of three new species. Proceedings of the Biological Society of Washington 116: 515-527.

Carter, H.J. (1873). On two new species of Gummineae, with special and general observations. Annals and Magazine of Natural History (4) 12: 17-30.

Carter, H.J. (1879). Contributions to our knowledge of the Spongida. Annals and Magazine of Natural History (5) 3: 284-304, 343-360.

Cavalcanti F.F, Zilberberg, C. and Klautau, M. (2007). Seasonal variation of morphological characters of Chondrilla aff. nucula (Porifera: Demospongiae) from the south-east coast of Brazil. Journal of the Marine Biological Association of the United Kingdom 87: 17271732.

Dendy, A. (1916). Report on the Homosclerophora and Astrotetraxonida collected by H.M.S. "Sealark" in the Indian Ocean. Transactions of the Linnean Society of London (2) 17: 225-271.

Desqueyroux-Faundez, R. and Soest, R. W. M. van. (1997). Shallow water Demosponges of the Galápagos Islands Revue Suisse de Zoologie 104: 379-467.

Dey, J., Aravena-Roman, M., Mee, B.J., Fromont, J. and Sutton D.C. (2004). Bacterial diversity and antibiotic activity in temperate Australian marine sponges (pp. 263-277). In: Pansini, M., Pronzato, R., Bavestrello, 
G. and Manconi, R. (eds.). Proceedings of the $6^{\text {th }}$ International Sponge Conference Italy 2002. Bolletino del Musei e deggli Instituti, Biologici dell'Universita di Genoa.

Edgar, G.J. (1997). Australian Marine Life, the plants and animals of temperate waters. Reed: Victoria.

Fromont, J. (1999). Reproduction of some demosponges in a temperate Australian shallow water habitat. Memoirs of the Queensland Museum 44: 185-192.

Fromont, J. and Garson, M. (1999). Sponge bleaching on the west and east coasts of Australia. Coral Reefs 18: 340.

Gray, J.E. (1872). Notes on the classification of the sponges. Annals and Magazine of Natural History (4) 9: 442-461.

Hentschel, E. (1912). Kiesel- und Hornschwämme der Aru- und Kei-Inseln. Abhandlungen herausgegeben von de Senckenbergischen naturforschenden Gesellschaft 34: 293-448.

Hooper, J.N.A. and Wiedenmayer, F. (1994). Porifera. In: Wells, A. (ed.), Zoological Catalogue of Australia, vol. 12. CSIRO: Melbourne.

Keller, C. (1891). Die Spongienfauna des Rothen Meeres. (II. Halfte). Zeitschrift für wissenschaftliche Zoologie 52: 294-368.

Kirkpatrick, R. (1900). On the sponges of Christmas Island. Proceedings of the Zoological Society of London 1900: 127-141.

Klautau, M. Russo, C. A. M. Lazoski, C. Boury-Esnault, N. Thorpe, J. P. and Solé-Cava, A. M. (1999). Does cosmopolitanism result from overconservative systematics? A case study using the marine sponge Chondrilla nucula. Evolution 53: 1414-1422.

Kumar, A. (1925). Report on some tetraxonid sponges in the collection of the Indian Museum. Records of the Indian Museum 27: 211-229.

Laubenfels, M.W. de (1936). A discussion of the Sponge Fauna of the Dry Tortugas in particular, and the West Indies in general, with material for a Revision of the Families and Orders of the Porifera. Carnegie Institute of Washington (Tortugas Laboratory Paper No. 467) 30: $1-225$.

Lendenfeld, R. von (1885). A monograph of the Australian sponges. Part 4. Proceedings of the Linnaean Society, New South Wales 9: 3-22.

Lendenfeld, R. von (1897). Die Clavulina der Adria. Nova acta Academie Caesareae Leopoldino Carolinae Germanicae Naturae Curiosorum 69: 1-251.

Meylan, A. (1988). Nutritional characteristics of sponges in the diet of the Hawksbill Turtle, Eretmochelys imbricate (pp. 472-477). In: Rützler, K. (ed.), New Perspectives in Sponge Biology. Smithsonian Institution Press: Washington D.C.

Randall, J.E. and Hartman, W.D. (1968). Sponge-feeding fishes of the West Indies. Marine Biology 1: 216-225.

Schmidt, O. (1862). Die Spongien des adriatischen Meeres. Wilhelm Engelmann: Leipzig.

Schulze, F.E. (1877). Untersuchungen über den Bau und die Entwicklung der Spongien. Dritte Mittheilung. Die Familie der Chondrosidae. Zeitschrift für Wissenschaftliche Zoologie 52: 294-368.
Thiele, J. (1900). Kieselschwämme von Ternate. I. Abhandlungen herausgegeben von der Senckenbergischen Naturforschenden Gesellschaft 25: 19-80.

Usher, K.M. and Ereskovsky, A.V. (2005). Larval development, ultrastructure and metamorphosis in Chondrilla australiensis Carter, 1873 (Demospongiae, Chondrosida, Chondrillidae). Invertebrate Reproduction and Development 47: 51-62.

Usher, K.M., Kuo, J., Fromont, J. and Sutton, D.C. (2001). Vertical transmission of cyanobacterial symbionts in the marine sponge Chondrilla australiensis (Demospongiae). Hydrobiologia 461: 9-13.

Usher, K.M., Sutton, D.C., Toze, S., Kuo, J. and Fromont, J. (2004a). Biogeography and phylogeny of Chondrilla species (Demospongiae) in Australia. Marine Ecology Progress Series 270: 117-127.

Usher, K.M., Sutton, D.C., Toze, S., Kuo, J. and Fromont, J. (2004b). Sexual reproduction in Chondrilla australiensis (Porifera: Demospongiae). Marine and Freshwater Research 55: 123-134.

Usher, K.M., Fromont, J., Sutton, D.C. and Toze S. (2004c). The biogeography and phylogeny of unicellular cyanobacterial symbionts in selected sponges from Australia and the Mediterranean. Microbial Ecology 48: 167-177.

Usher, K.M., Sutton, D.C., Toze, S., Kuo, J. and Fromont, J. (2005). Inter-generational transmission of microbial symbionts in the marine sponge Chondrilla australiensis (Demospongiae). Marine and Freshwater Research 56: 125-131.

Vilanova, E., Zilberberg, C., Kochen, M., Custódio, M.R. and Mourão, P.A.S. (2007). A novel biochemical method to distinguish cryptic species of Chondrilla (Chondrosida, Demospongiae) based on its sulfated polysaccharides (pp. 653-659). In: Custódio, M.R., Lôbo-Hajdu, G., Hajdu, E. and Muricy, G. (eds.), Porifera Research: Biodiversity, Innovation and Sustainability. Museu Nacional: Rio de Janeiro.

Wilkinson, C. R. (1983). Phylogeny of bacterial and cyanobacterial symbionts in marine sponges (pp. 993-1002). In: Schenk, H.E.A. and Schwemmler, W. (eds), Endocytobiology, volume II. Intracellular Space as Oligogenetic Ecosystem. Proceedings of the 2 nd International Colloguium on Endocytobiology. Walter de Gruyter: Berlin.

Wilkinson, C.R. (1992). Symbiotic interactions between marine sponges and algae (pp. 112-151). In: Reisser, W. (ed.), Algae and Symbiosis: Plants, Animals, Fungi, Viruses. Interactions Explored. Biopress Ltd: Bristol.

Wilson, B. and Clarkson, P. (2004). Australia's spectacular cowries. a review and field study of two endemic genera: Zoila and Umbilia. Odyssey: USA.

Zilberberg, C., Solé-Cava, A.M. and Klautau, M. (2006). The extent of asexual reproduction in sponges of the genus Chondrilla (Demospongiae: Chondrosida) from the Caribbean and the Brazilian coasts. Journal of Experimental Marine Biology and Ecology 336: 211-220.

Manuscript received 26 May 2008; accepted 17 September 2008. 


\section{Part 1}

\section{Allan H. Burbidge}

What was the Jarnadup Bristlebird?

Mark S. Harvey and Karen L. Edward

Three new species of cavernicolous goblin spiders (Araneae, Oonopidae) from Australia

Brian Morton

The evolution of the watering pot shells (Bivalvia: Anomalodesmata: Clavagellidae and Penicillidae)

Natalie R. Franklin

Aboriginal engravings in the southwest of Western Australia: analysis of the Kybra Site

John E. Randall

Leptachirus, a new soleid fish genus from New Guinea and northern Australia, with descriptions of eight new species

John E. Randall and Gerald R. Allen

Aseraggodes crypticus, a new Sole (Pleuronectiformes: Soleidae) from Christmas Island, Indian Ocean

\section{Part 2}

\section{Melinda L. Moir and Mark S. Harvey}

Discovery of the pill millipede genus Epicyliosoma (Diplopoda: Sphaerotheriida:

Sphaerotheriidae) in Western Australia, with the description of a new species

Paul Doughty and Danielle Edwards

A new species of Arenophryne (Anura: Myobatrachidae) from the central coast of Western Australia

\section{Marion Anstis}

Direct development in the Australian myobatrachid frog Metacrinia nichollsi from Western Australia

\section{Martin Baehr}

New and rare pseudomorphine species from Western Australia (Insecta,

Coleoptera, Carabidae, Pseudomorphinae)

Yu Wen

On the genus Yangtzemerisma and related genera (Mollusca: Merismoconchia)

\section{Christer Erséus}

A new species, Olavius ulrikae (Annelida: Clitellata: Tubificidae), re-assessment of a Western Australian gutless marine worm

\section{Martin Baehr}

A new cavernicolous and eyeless species of the genus Lymnastis from Christmas

Island, Australia (Insecta: Coleoptera: Carabidae: Bembidiinae)

Dirk Fehse and Jozef Grego

New species of the genus Trivellona (Mollusca: Gastropoda) from the Miocene of Australia

Elizabeth M. Exley

A replacement name for the bee Euhesma sulcata Exley (Hymenoptera: Colletidae: Euryglossinae) 


\section{Part 3}

Thomas A. Darragh and George W. Kendrick

Silicified Eocene molluscs from the Lower Murchison district, Southern Carnarvon

Basin, Western Australia

Paul Doughty, Paul Oliver and Mark Adams

Systematics of stone geckos in the genus Diplodactylus (Reptilia: Diplodactylidae) from northwestern Australia, with a description of a new species from the Northwest

Cape, Western Australia

Ivana Karanovic

Three interesting Cyprididae (Ostracoda) from Western Australia

Brian V. Timms

Further studies on the fairy shrimp genus Branchinella (Crustacea, Anostraca,

Thamnocephalidae) in Western Australia, with descriptions of new species

R. Esmée Webb and Alana M. Rossi

How was Mulka's Cave, an Aboriginal rock art site near Hyden, in south-central Western Australia, used by the people who decorated its walls, when the present entrance was much smaller?

\section{Part 4}

\section{Mark Harvey and Paul Doughty}

\section{Preface}

Barbara York Main

A new species of the mygalomorph spider genus Yilgarnia from the Western Australian wheatbelt (Araneae: Nemesiidae)

Barbara C. Baehr and Helen M. Smith

Three new species of the Australian orsolobid spider genus Hickmanolobus (Araneae: Orsolobidae)

Ricardo Ott and Mark S. Harvey

A new species of Xestaspis (Araneae: Oonopidae) from the Pilbara region of Western Australia

Michael G. Rix

A new species of Micropholcomma (Araneae: Araneoidea: Micropholcommatidae) from Western Australia 343

Norman I. Platnick and Nadine Dupérré

A new species of the spider genus Notsodipus (Araneae: Lamponidae) from Western Australia

Robert J. Raven

Revisions of Australian ground-hunting spiders: III. Tuxoctenus gen. nov. (Araneomorphae: Zoridae)

Volker W. Framenau

A new wolf spider species of the genus Artoria from Western Australia (Araneae: Lycosidae)

Julianne M. Waldock

A new species of Maratus (Araneae: Salticidae) from southwestern Australia

Christopher Taylor

A new species of Monoscutidae (Arachnida, Opiliones) from the wheatbelt of Western Australia 
Mark S. Harvey and Mei Chen Leng

Further observations on Ideoblothrus (Pseudoscorpiones: Syarinidae) from subterranean

environments in Australia

Mark S. Harvey and Mei Chen Leng

The first troglomorphic pseudoscorpion of the family Olpiidae (Pseudoscorpiones), with remarks on the composition of the family

Terrie L. Finston, Michael S. Johnson, Brenton Knott

A new genus and species of stygobitic paramelitid amphipod from the Pilbara, Western Australia

Ivana Karanovic

A new species of the genus Candonopsis (Crustacea, Ostracoda) from Western Australia

Roger N. Bamber

A new species of the freshwater tanaidacean genus Pseudohalmyrapseudes (Crustacea: Tanaidacea:

Parapseudidae) from Sulawesi

Murray J. Fletcher and Melinda L. Moir

Gunawardenea, a new genus of squat leafhoppers from Western Australia, with description of two new species (Hemiptera: Cicadellidae: Deltocephalinae)

L. Krogmann, M.C. Day and A.D. Austin

A new spider wasp from Western Australia, with a description of the first known male of the genus Eremocurgus (Hymenoptera: Pompilidae)

Emily A. Glover and John D. Taylor

Callucina and Pseudolucinisca (Mollusca: Bivalvia: Lucinidae) from Australia: revision of genera and description of three new species

Adrian M. Pinder

Phreodrilidae (Clitellata: Annelida) in north-western Australia with descriptions of two new species

J. Fromont, K.L. Usher, D.C. Sutton, S. Toze and J. Kuo

Species of the sponge genus Chondrilla (Demospongiae: Chondrosida: Chondrillidae) in Australia 


\section{INDEX TO AUTHORS}

Adams, $\mathrm{M}$.

Allen, G.R.

Anstis, $\mathrm{M}$.

Austin, A.D.

Bamber, R.N.

Baehr, M.

Burbidge, A.H.

Darragh, T.A.

Day, M.C.

Doughty, P.

Dupérré, $\mathrm{N}$.

Edwards, D.

Edwards, K.E.

Erséus, C.

Exley, E.M.

Fehse, D.

Finston, T.L.

Fletcher, M.J.

Framenau, V.M.

Franklin, N.R.

Fromont, J.

Glover, E.A.

Grego, J.

Harvey, M.S.

Johnson, M.S.

Karanovic, I.
$247 \quad$ Kendrick, G.W.

109 Knott, B.

133 Krogmann, L.

437 Kuo, J.

469

421 Leng, M.C.

379,387

151, 199, $325 \quad$ Main, B.M.

321

1 Moir, M.L.

113,429

217 Morton, B.

437 Oliver, $\mathrm{P}$

$121,247,319 \quad$ Otto, $R$.

337

349 Pinder, A.M. 459

121 Platnick, N.I. 349

9 Randall, J.E. 81, 109

195 Raven, R.J. 351

215 Rix, M.G. 343

205 Rossi, A.M. 307

395 Smith, H.M.

429 Sutton, D.C. 469

363 Taylor, C. 375

65 Taylor, J.D. 443

469 Timms, B.V. 289

443 Toze, $\mathrm{S} . \quad 469$

205 Usher, K.L. 469

9, 319, 337, 379, $387 \quad$ Waldock, J.M. 369

395 Webb, R.E. 307

267, 411 Yu Wen 181 


\section{Guide to Authors}

\section{Subject Matter}

Original research, reviews and observations in all branches of natural science and human studies will be considered for publication. However, emphasis is placed on studies pertaining to Western Australia and neighboring regions. Longer papers will be considered for publication as Supplements to the Recorts of the Western Alsstralian Musemm. Such publications may attract charges to the authors to offset the costs of printing - authors should consult the editors before submitting large manuscripts. Short communications should not normally exceed three typed pages and this category of paper is intended to accommodate observations, results or new records of significance. All material must be original and not have been published elsewhere.

\section{Presentation}

Authors are advised to follow the lavout and style in the most recent issue of the Records of the Western Australion Musemm including headings, tables, illustrations and references. When in doubt, use a simple format that is easily edited. Please provide line numbers throughout the MS (e.g., in Word go to File $\rightarrow$ Page Setup $\rightarrow$ Layout (tab) $\rightarrow$ Line Numbers (button), add line numbers and click on "continuous" numbering).

The title should be concise, informative and contain key words necessary for retrieval by modern searching techniques. An abridged title (not exceeding 50 character spaces) should be included for use as a running head.

An abstract must be given in full length papers but not short communications, summarizing the scope of the work and principal findings. It should normally not exceed $2 \%$ of the paper and be suitable for reprinting in reference periodicals. At the end of the abstract, provide several keywords not already included in the title.

The International System of units should be used. Spelling should follow the Concise Oxford Dictionary. Numbers should be spelled out from one to nine in descriptive text; figures used for 10 or more. For associated groups, figures should be used consistently (e.g." "5 to 10 ", not "five to 10 ").

Systematic papers must conform with the International Codes of Botanical and Zoological Nomenclature and, as far as possible, with their recommendations.

Synonymies should be given in the short form (taxon, author, date, page) and the full reference cited at the end of the paper. All citations, including those associated with scientific names in taxonomic works, must be included in the references.

\section{Manuscripts}

Manuscripts should be submitted electronically as PDF's or Word files to the editors (listed below). For manuscripts with large image files, submission of a CD is acceptable. Manuscripts must be 1.5 or double-spaced throughout All margins should be at least $25 \mathrm{~mm}$ wides. Tables plus headings, and Figure legends should be on separate pares Tables should be numbered consecutively, have headings which make them understandable without references to the text, spell out generic names and be referred to in the text.

Fisures

Lower resolution imagescan be inserted into a PDF or Word document for review. Upon aceptanoe, high resolution (o10 Mby images in THF or flleciformat can be e-maled or burned to CD and posted to the editors. We prefer TIFr files for figures. For Adobe Illustrator and Sigmaplot, save in eps (encapsulated postscript) format; for PowerPoint, save in . w $\mathrm{mf}$ (windows metafile format); for Excel, save as Excel 97 worksheet (must contain spreadsheet and embedded chart); and for CorelDraw, save as an eps file that may be opened by Adobe lllustrator.

Scanned photographs should be saved as TIFF files. All TIFF files should be compatible with Adobe Photoshop. If figures are prepared in a paint program, for black-andwhite line art save at 600 dpi as a black-and-white bitmap (not greyscale or colour), and greyscale and colour line art at $300 \mathrm{dpi}$

Scale must be indicated on illustrations. Use arrows or other aids to indicate specific features mentioned in the text. All maps, line drawings, photographs and graphs should be numbered in sequence and referred to as "Figure" (no abbreviation) in the text and captions. Each figure should have a brief, fully explanatory caption.

\section{References}

In the body of the text, references should be cited as follows:

McKenzie and colleagues (McKenzie 1999, 2000; Mckenzie of al. 2000) found that bat frequencies were highest on full moons, contra previous workers (Smith and Jones 1982; Berman 1988; Zucker et al. 1992).

For citing taxonomic groups and the author, a comma occurs between them:

The family Carphodactylidae consists of Carphodactylus Smith, 1999, Neplrurus Jones, 1999, Orroya Couper, Covacevich and Hoskin, 2001, Plyyllurws Sprong, 1888 and Saltuarius Hammond, 1901.

All references must be cited in the text by author and date and all must be listed alphabetically at the end of the paper. The names of journals are to be given in full. Consult a recent edition of the Reconts for style. For taxonomic papers, include full references for all taxonomic groups mentioned in the text. In manuscripts dealing with historical subjects references may be cited as footnotes.

\section{Processing}

All manuscripts are reviewed by at least two referees whose reports assist the editors in making their decision whether to accept the paper. The review process usually takes from one to three months, although the review process and typesetting for longer manuscripts and supplements are usually longer.

The senior author is sent one set of page proots electronically which must be returned within one week after receipt.

The senior author will receive 25 tree reprints, a PDF and a copy of the entire issue. Additional offprints can be ordered at page proof stage.

\section{Editors}

Manuscripts an be submitted to sither Paul Doughty (pauldoughtyomuseumwagovau); human studies lanthropology, archatology or historst and sertebrate animals) or Mark Harves (mark harveyemusem magrow au); invertebrate animals) 


\section{Records of the Western Australian Museum Volume 24 Part 42008}

\section{Preface}

\section{CONTENTS}

\section{Barbara York Main}

A new species of the mygalomorph spider genus Yilgarnia from the Western Australian wheatbelt

(Araneae: Nemesiidae)

Barbara C. Baehr and Helen M. Smith

Three new species of the Australian orsolobid spider genus Hickmanolobus (Araneae: Orsolobidae)

Ricardo Ott and Mark S. Harvey

A new species of Xestaspis (Araneae: Oonopidae) from the Pilbara region of Western Australia

Michael G. Rix

A new species of Micropholcomma (Araneae: Araneoidea: Micropholcommatidae) from Western Australia

\section{Norman I. Platnick and Nadine Dupérré}

A new species of the spider genus Notsodipus (Araneae: Lamponidae) from Western Australia

Robert J. Raven

Revisions of Australian ground-hunting spiders: III. Tuxoctenus gen. nov. (Araneomorphae: Zoridae)

Volker W. Framenau

A new wolf spider species of the genus Artorla from Western Australia (Araneae: Lycosidae)

Julianne M. Waldock

A new species of Maratus (Araneae: Salticidae) from southwestern Australia

Christopher Taylor

A new species of Monoscutidae (Arachnida, Opiliones) from the wheatbelt of Western Australia

Mark S. Harvey and Mei Chen Leng

Further observations on Ideoblothrus (Pseudoscorpiones: Syarinidae) from subterranean environments in Australia

\section{Mark S. Harvey and Mei Chen Leng}

The first troglomorphic pseudoscorpion of the family Olpiidae (Pseudoscorpiones), with remarks on the composition of the family

Terrie L. Finston, Michael S. Johnson, Brentot Knott

A new genus and species of stygobitic paramelitid amphipod from the Pilbara, Western Australia

Ivana Karanovic

A new species of the genus Candonopsis (Crustacea, Ostracoda) from Western Australia

\section{Roger N. Bamber}

A new species of the freshwater tanaidacean genus Pseudohalmyrapseudes (Crustacea: Tanaidacea:

Parapseudidae) from Sulawesi

Murray J. Fletcher and Melinda L. Moir

Gunawardenea, a new genus of squat leafhoppers from Western Australia, with description of two new species (Hemiptera: Cicadellidae: Deltocephalinae)

L. Krogmann, M.C. Day and A.D. Austin

A new spider wasp from Western Australia, with a description of the first known male of the genus Eremocurgus (Hymenoptera: Pompilidae)

Emily A. Glover and John D. Taylor

Callucina and Pseudolucinisca (Mollusca: Bivalvia: Lucinidae) from Australia: revision of genera and description of three new species

\section{Adrian M. Pinder}

Phreodrilidae (Clitellata: Annelida) in north-western Australia with descriptions of two new species 